\title{
Przekształcenia centrów małych i średnich miast - dawne a nowe znaczenie historycznych przestrzeni miejskich w wybranych ośrodkach Mazowsza
}

\author{
Izabela Sobierajska, Małgorzata Ewa Sikorska
}

\begin{abstract}
STRESZCZENIE
Celem niniejszego opracowania jest przedstawienie współczesnych problemów zagospodarowania i funkcjonowania historycznych, pierwotnych centrów miejskich w małych i średnich miastach na Mazowszu. Analizowane miasta podzielono na historyczne, o rodowodzie lokacyjnym i przedlokacyjnym oraz na miasta nowe, XIX i XX-wieczne. Centra miast historycznych mają w większości z nich swoją ugruntowaną pozycję i zachowują w większym lub mniejszym stopniu swoją tożsamość. W części tych miast centra utraciły po części swoje znaczenie, głównie z powodu zaniku bądź relokacji funkcji handlowych, bądź z powodu prowadzenia ruchu tranzytowego przez dawną strefę centralną. Czasem przyczyną dodatkową jest degradacja zabudowy, jak i zagospodarowania głównych przestrzeni publicznych.

Artykuł zawiera ogólne sugestie proponowanych działań wzmacniających przede wszystkim znaczenie ogólnomiejskie centrum miejskiego, zwłaszcza w miastach starych. Dla miast nowych zawarto wskazówki możliwych działań wzmacniających proces kształtowania się centrum.
\end{abstract}

Słowa kluczowe: Góra Kalwaria, Karczew, Mława, Otwock, Piastów, Mazowsze, małe i średnie miasta, rynek miejski, centrum miasta

\section{Wprowadzenie}

Proces kształtowania przestrzeni miejskiej jest procesem długotrwałym i indywidualnym dla każdego miasta. Miasta różnią się okresem powstania, walorami przyrodniczymi, kulturowymi, przestrzennymi, architektonicznymi, w tym także uwarunkowaniami społecznymi i gospodarczymi. Przekształcenia struktur przestrzennych odmienne są dla każdego z ośrodków miejskich, w jakich są przeprowadzane. Zależą one od potencjału danego miasta i oczekiwanych rezultatów - dotyczy to w sposób szczególny centralnych terenów miast.

Centrum -obszar szczególny w strukturze każdego miasta, tereny największejkoncentracji kontaktów, lokalizacji struktur wielofunkcyjnych, ale także miejsce występowania problemów społecznych i techniczno-materialnych - podlega ciągłym przekształceniom, zarówno programowym, modernizacyjnym, jak i estetycznym; charakterystyczne jest dla niego zjawisko wypierania funkcji mniej rentownych. Do zadań centrum w dużej mierze należy utrzymanie roli i pozycji miasta w konkurencyjnym otoczeniu. Centrum, stanowiące rdzeń miasta, charakteryzuje się zwykle wyższą intensywnością zabudowy i jest środowiskiem całkowicie antropogenicznym [Nowakowski 1990; Pazyra 1959; Zemło 2003]. 
Przekształcenia obszarów centralnych miast przybierają różne formy. Są to przeobrażenia wynikające z sukcesywnej wymiany istniejących struktur, planowych przeobrażeń, bądź z działań spontanicznych, nieskoordynowanych; ich kierunek w znaczącym stopniu zależy nie tyle od potencjału społeczno-gospodarczo-przestrzennego czy kulturowego centralnych stref miejskich, ile od polityki przestrzennej władz miasta, w tym ich umiejętności tego potencjału odczytania

\section{Rys historyczny - kształtowanie się i znaczenie centrów w rozwoju miast Mazowsza}

Odmiennie kształtowały się centra miast lokacyjnych, o wielosetletniej tradycji miejsca i funkcji, a inaczej powstały centra miast wykształconych w XIX i XX w. Różne też były i są ich najnowsze przemiany i problemy funkcjonowania.

\section{Miasta lokacyjne}

W małych i średnich miastach, powstałych w okresie średniowiecza czy nowożytnym, ich centra kształtowały się zwyczajowo wokół rynku miejskiego, który w większości miast europejskich od czasów średniowiecza stanowił „serce miasta” [Adamczewska-Wejchert, Wejchert 1986]. Ta główna przestrzeń miejska związana była z funkcją handlową i częściowo reprezentacyjną. W taki sposób ukształtowały się centra np. Karczewa, Mławy ${ }^{1}$, Węgrowa czy Radzymina [Mława 1885].

W Górze Kalwarii pierwsza, jeszcze przedlokacyjna osada, funkcjonowała w XII w., jako wieś rycerska zlokalizowana przy przeprawie przez Wisłę, w sąsiedztwie starszego grodu obronnego, Czerska. Pozostałością po tej części historii miasta jest dawny plac targowy przylegający do ul. św. Antoniego. Położenie na szlaku handlowym Płock - Sandomierz wpływało na dalszy rozwój osady do drugiej połowy XVII w. Życie ludności skupiało się wokół placu targowego.

W latach 1666-1687 w Górze Kalwarii powstał - poza układem osiedleńczym miasta - układ kalwaryjski tzw. Nowej Jerozolimy, układ przestrzenny dwóch dróg tworzących kształt krzyża, wraz z systemem dominant - kościołów i kaplic. Na przecięciu ramion krzyża powstał plac miejski z kościołem zamykającym główną oś kompozycyjną od wschodu, na granicy skarpy wiślanej. Na samym skrzyżowaniu ramion krzyża (osi) ustawiono jedną z głównych kaplic drogi kalwaryjskiej (obecnie drugi kościół na rynku). Dotychczasowy charakter miasta zmienił się z handlowego na miejscowość pielgrzymkową. Nietypowość założenia polegała na tym, że układ kalwaryjski został w tym przypadku wpleciony, wkomponowany w układ ulic i placów miejskich [Bobko 2013]. Jednakże to właśnie koncentracja na jednym obszarze pięciu zakonów i oparcie ekonomii miasta na dochodach z ruchu pielgrzymkowego przyczyniły się do gospodarczego upadku miasta w stosunkowo krótkim czasie - kalwaria funkcjonowała zaledwie około 100 lat. Dodatkowo miasto uległo zniszczeniu w czasie insurekcji kościuszkowskiej w 1794 r.

\footnotetext{
${ }^{1}$ Obszerny artykuł, autorstwa I. Sobierajskiej i T. Wyszyńskiej, pt.: Przemieszczanie się centrum Mławy w historii jej rozwoju - znaczenie centrotwórcze stacji Mława Miasto, ukazał się w kwartalniku MAZOWSZE Studia Reguinalne, 2018, 24, s. 85-104.
} 
Przejęcie dóbr kościelnych przez rząd Prus oraz przeniesienie w 1815 r. do Góry Kalwarii siedziby powiatu z Czerska przyczyniły się do ponownego rozwoju młodego miasta. Program rządowy zaowocował regulacją i wybrukowaniem ulic, realizacją rogatek i rzeźni. W latach 1829-34 na rynku powstał neoklasycystyczny ratusz, do którego na zapleczu dobudowano, jako skrzydła, boczne kramy mieszczące 16 sklepów. Nowa zabudowa w północnej pierzei rynku zniwelowała częściowo dawny układ ramienia krzyża. To rejon północnej części planu i kwartały położone na północ od rynku, jako pierwsze zostały poddane nowemu osadnictwu. Do miasta powrócił handel stanowiący główną część działalności mieszkańców, w tym nowo osiedlonych kupców żydowskich oraz rzemieślników. Plac miejski pełnił rolę targowiska jeszcze na początku XX w. Jednocześnie osiedlenie się w mieście cadyków z dynastii Ger uczyniło z Góry Kalwarii jeden z głównych ośrodków religii żydowskiej na obszarze dzisiejszej Polski (ryc. 1, 2, 3).
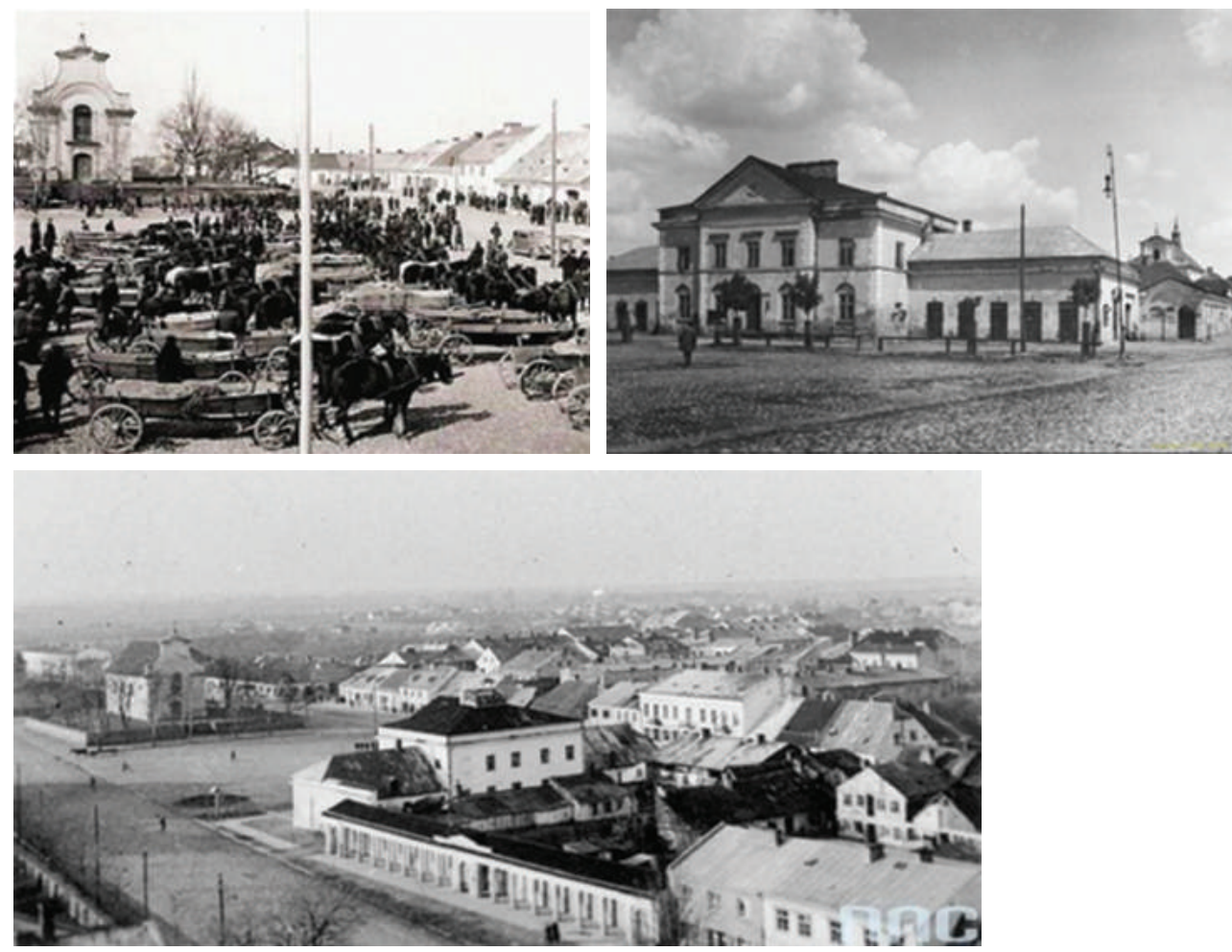

Ryc. 1., 2., 3. Widoki na targ na rynku i ratusz w Górze Kalwarii oraz na kramy przy ratuszu Źrodło: Domena publiczna

Ten okres rozwoju miasta, jako jednego z miasteczek żydowskich II Rzeczypospolitej, skończył się wraz z II wojną światową. Zanikła także w znacznym stopniu tradycyjna, handlowa funkcja rynku. Pozostała natomiast funkcja administracyjna. 
W pobliskim Karczewie osada przedlokacyjna istniała już w XIII w. w rejonie obecnego Starego Miasta, na trakcie handlowym prowadzącym przez bród na Wiśle do Gassów [Borkowska 2002; Gawryluk 2012]. Głównymi elementami osady były rozległy plac targowy i kościół. Na placu handlowano płodami rolnymi uprawianymi przez okolicznych chłopów, jak i produktami wytwarzanymi przez miejscowych rzemieślników. Wokół placu istniały karczmy obsługujące głównie ruch handlowy na przeprawie - elemencie Szlaku Bursztynowego.

Targowe znaczenie Karczewa wzrosło jeszcze po lokacji na prawie chełmińskim w 1548 r. przez króla Zygmunta Starego. W bezpośrednim sąsiedztwie starego, powstał nowy, równie rozległy rynek lokacyjny. Otoczyły go budynki parterowe, drewniane, o wysokich kalenicowo ułożonych dachach. Zgodnie z przywilejem lokacyjnym miały się w mieście odbywać dwa jarmarki coroczne oraz cotygodniowe, w soboty. Pozwoliło to na sukcesywny rozwój miasta do przełomu XVI i XVII w.

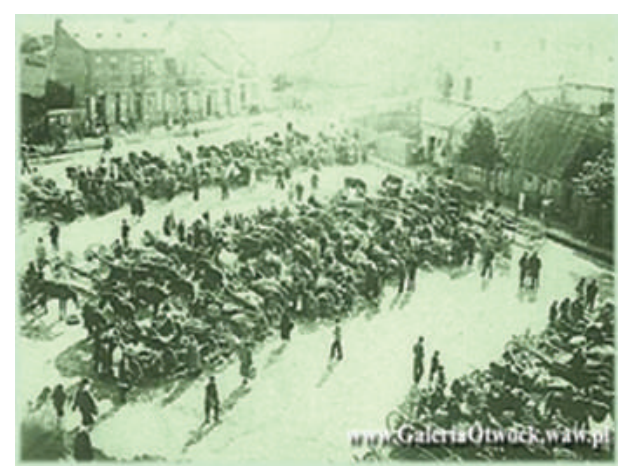

Ryc. 4. Widok z wieży remizy strażackiej na jarmark na rynku - dwudziestolecie międzywojenne Źrodło: Domena publiczna

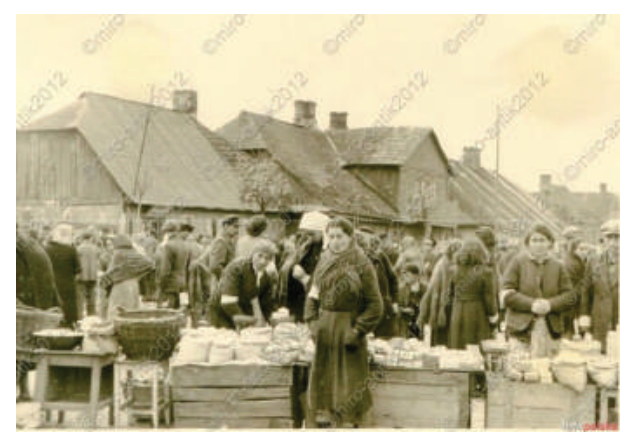

Ryc. 5. Targ na rynku Starego Miasta, lata 1940-41 Źrodło: Domena publiczna
Zniszczenia wojenne oraz pożary w XVII w. spowolniły rozwój miasta, który przyspieszył ponownie na przełomie wieku XVII i XVIII, po wydaniu nowego przywileju lokacyjnego. W strukturze miasta w II połowie XVIII w. powstał kolejny plac - tzw. Świński Rynek. Ten trzeci plac miejski, położony na obrzeżach ówczesnego układu miejskiego, związany był $z$ ubojem i handlem wieprzowiną i jako uciążliwyniesąsiadowałbezpośredniozdwoma pierwszymi. Kolejne zniszczenia miasta w XIX w. nie załamały jego gospodarki, tradycyjnie opartej na handlu - rocznie odbywało się tu już 48 targów i 13 jarmarków. Dodatkowo, połowa mieszkańców utrzymywała się z rzemiosła.

Spadek znaczenia miasta $\mathrm{w}$ strukturze osadniczej i istotne przekształcenia spowodowane zostały realizacją $\mathrm{w}$ pewnym oddaleniu od miasta linii kolejowej Kolei Nadwiślańskiej. Karczew przegrał konkurencję z Falenica, Józefowem i Otwockiem, nowymi miastami o genezie z końca XIX w., które swój rozwój zawdzięczają właśnie bezpośredniemu dostępowi do stacji kolejowych. Tylko na chwilę rozwój Karczewa i znaczenie jego strefy centralnej utrzymała linia kolei wąskotorowej, doprowadzona do osady z centrum Warszawy w 1914 r. (ryc. 4, 5). 
Tradycja handlowa na placach miejskich, w tym przede wszystkim na Placu Zygmunta Starego w Karczewie, zachowała się jeszcze w dwudziestoleciu międzywojennym. Pośrodku rynku, na początku lat 30. XX w., stanęła remiza straży pożarnej, której bryła podzieliła jego przestrzeń na 3 części. Znaczenie placu miejskiego uległo zmianie po II wojnie światowejfunkcja handlowa została mocno ograniczona, funkcja administracyjna została relokowana poza zespół lokacyjny (ryc. 6).

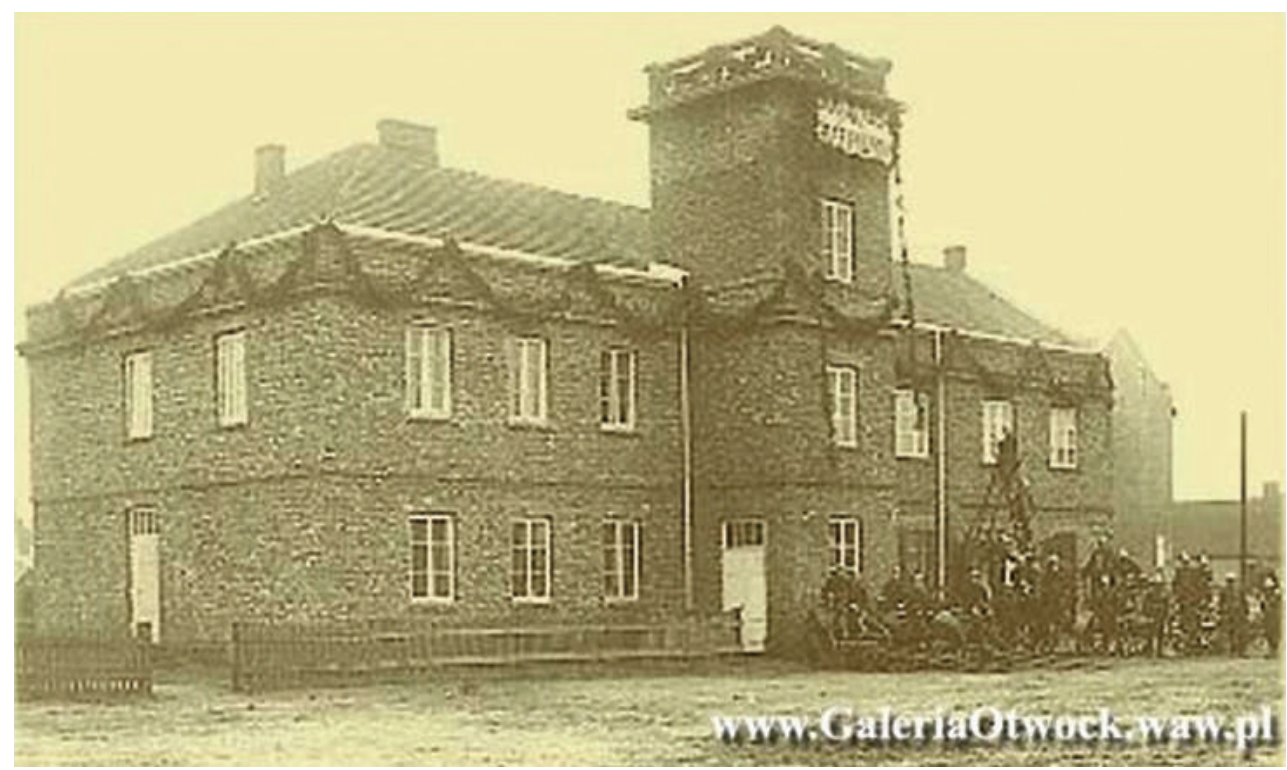

Ryc. 6. Widok remizy strażackiej na Rynku Zygmunta Starego

Źrodło: Domena publiczna

\section{Nowe miasta}

Miasta XIX-wieczne kształtowały się często w inny sposób: Wołomin, Otwock czy Piastów powstały jako miasta w wyniku przekształcania i rozbudowy osad rekreacyjnych czy produkcyjnych. Ich lokalizacja warunkowana była umiejscowieniem stacji linii kolejowych prowadzących do Warszawy.

Przykładem miasta, którego powstanie wiąże się ze stacjami linii kolejowych jest Otwock. Początki jego rozwoju sięgają końca XIX w. i związane są z budową Kolei Nadwiślańskiej (ryc. 7, 8).

Początkowy rozwój miasta związany jest z osobą Michała Elwiro Andriollego - rysownika i malarza, który nabywając w 1880 r. 200 ha ziemi zaczął budować domy letniskowe. Sprawne połączenie kolejowe ze stolica, liczne festyny i festiwale przyciągały w te okolice ludzi kultury, sztuki, którzy swój pobyt w Otwocku zaczęli opisywać w prasie warszawskiej, co przyczyniło się do jego dynamicznego rozwoju. 


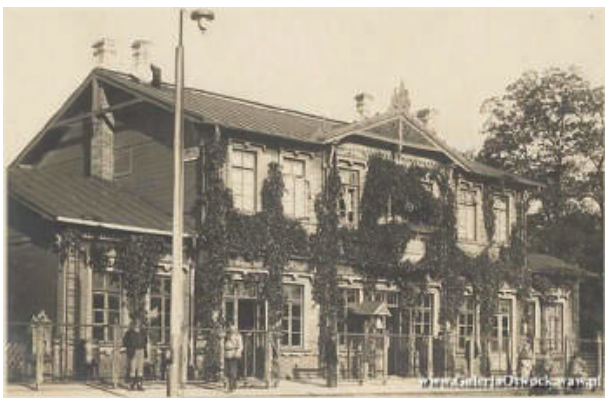

Ryc. 7. Pierwszy budynek dworca kolejowego (wyb. 1876-77) Źrodło: Domena publiczna

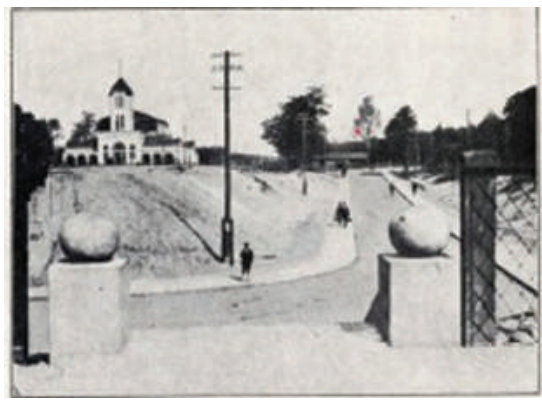

Ryc. 8. Widok na nowy dworzec kolejowy (wyb. 1910) Pocztówka z 1925 r. Źrodło: Domena publiczna

Dalszy rozwój miasta związany jest z otwarciem w roku 1893 nizinnego sanatorium chorób płuc, co przyczyniło się do powstawania kolejnych sanatoriów leczących gruźlicę oraz choroby płuc, ale także pensjonatów. W 1917 r. w Otwocku znajdowały się już 3 sanatoria i 22 pensjonaty.

Otwock stawał się miastem wypoczynkowym i sanatoryjnym, o czym decydował jego potencjał przyrodniczy, w tym unikatowy klimat, związany z występowaniem sosny karłowatej, wydzielającej specyficzne olejki eteryczne, korzystne przy leczeniu chorób dróg oddechowych, a także malownicze tereny o potencjale rekreacyjnym, związane z rzeką Świder.

Dzięki szybkiej komunikacji zapewniającej łatwą komunikację z Warszawą zaczęły się rozwijać tereny wokół dworca kolejowego, a także powstawać w jego pobliżu oraz w sąsiedztwie sanatoriów lokalizowanych na wzgórzu Meran liczne wille i obiekty lecznicze, a w strefie nadświdrzańskiej pensjonaty i ośrodki rekreacyjne.

W wyniku zabudowywania miasta obiektami, których lokalizacje były ściśle powiązane z wartościami przyrodniczo-rekreacyjnymi i klimatycznymi miasta powodującymi rozprzestrzenianie się zabudowy w różnych strefach jego obszaru, w Otwocku nie wykształciło się tradycyjne centrum, które skupiałoby podstawowe dla niego funkcje administracyjnousługowe, mimo, że początki aktywności budowlanej w zakresie budynków usługowych w rejonie dworca kolejowego były wyraźne. Oprócz samego budynku dworca, który mieścił też funkcje gastronomiczne, zlokalizowano tu budynek administracyjny, w którym znajdowała się przychodnia lekarska. W sąsiedztwie dworca, przy placu, zbudowano hale targowe, w bliskim sąsiedztwie zlokalizowana była słynna restauracja Jarząbka. Niemniej rozwój przestrzenny centralnej części miasta Otwocka odbywał się zarówno w rejonie stacji kolejowej, jak i w związku z lokalizacjami ważniejszych obiektów od stacji oddalonych. Takimi były np. katolicki kościół, którego umiejscowienie przyczyniło się do rozwoju drobnych usług wzdłuż doprowadzającej do niego od stacji ulicy Kościelnej (po wschodniej stronie linii kolejowej) czy obiekt kasyna zlokalizowanego po południowo-zachodniej stronie linii kolejowej, w którym funkcjonowały: restauracja, kino, sala teatralna oraz sala gier hazardowych. Spowodowało to rozwój funkcji usługowych w ciagu ulicy Andriollego.

II wojna światowa spowodowała znaczne zniszczenia tkanki miejskiej, spadła też liczba ludności z 20 do 12 tysięcy. Obszar w centralnej strefie miasta wokół stacji, po obu jej stronach, 
został przekształcony w getto zlikwidowane w sierpniu 1942 r. Prawie jednocześnie, w trakcie działań na froncie w 1944 r., większość sanatoriów zamieniono na szpitale polowe i zdewastowano [Podhorecki (red.) 1998].

Najmłodsze spośród analizowanych miast, Piastów, powstało pod koniec XIX w. na terenach dawnych wsi. W rejonie nowej stacji kolejowej, na linii Kolei Żelaznej WarszawskoWiedeńskiej, w roku 1898 rozpoczęto realizację osiedla mieszkalnego dla pracowników kolejowych zakładów naprawczych, które istniały w pobliskiej wsi Żbikowo. Już na początku XX w. powstało obok drugie takie osiedle. Dla obsługi osiedli mieszkalnych funkcjonowały w niej m.in. kościół, szkoła powszechna i łaźnia publiczna. Po uzyskaniu niepodległości w osadzie zrealizowano, w pobliżu linii kolejowej, nowe zakłady produkcyjne, w znacznej mierze w układzie pasmowym równoległym do torów. Rozwijające się prężnie osiedle przemianowano w 1926 r. na Piastów. Samodzielność administracyjną, jako gmina, Piastów uzyskał w $1930 \mathrm{r}$.

\section{Przemiany przestrzenne centralnej części w małych i średnich miastach w II połowie XX wieku}

\section{Miasta lokacyjne}

Centra małych i średnich miast o genezie lokacyjnej, to zwykle rynek lokacyjny i sąsiadująca z nim, powstająca na kanwie ulicznej zabudowa. Obszary te, w przypadku niedużych miast, nadal powinny stanowić ich serca, związane z głównymi działalnościami $\mathrm{w}$ mieście. $\mathrm{W}$ drugiej połowie $\mathrm{XX} \mathrm{w}$. wiele historycznych, głównych przestrzeni miejskich, stanowiących kościec centralnej części miasta, straciło swoje historyczne, tradycyjne znaczenie. Powodów było wiele: zniszczenia wojenne i odbudowa miasta w innym kształcie i układzie funkcjonalnym, relokacja centrum wraz z rozwojem miasta, przypadkowe realizacje niszczące dotychczasowy układ przestrzenny lub po prostu brak pomysłu na ożywienie strefy historycznego centrum.

Plac miejski w Górze Kalwarii czy też system placów ze sobą sprzężonych, w centrum historycznego układu urbanistycznego w drugiej połowie XX w. stracił swój pierwotny, targowy i handlowy charakter. Główny plac miejski przekształcono w skwer, którego zieleń z czasem rozrosła się w sposób niekontrolowany (ryc. 9, 10).

Funkcje administracyjne ratusza „wprowadziły się" do dawnych kramów, eliminując skutecznie ze wschodniej i centralnej części placu funkcję handlowa, której pozostałości zachowały się jedynie w części parterów kamieniczek w zachodniej części placu.

Kwartały na północ od placu, w tym dawny ośrodek kultu religii żydowskiej, przekształcono na składy i magazyny oraz częściowo na zabudowę mieszkaniową. Ciąg usług handlowych i gastronomicznych zachował się przede wszystkim w pierzejach ul. Pijarskiej - dawnej pionowej, krótszej osi krzyża kalwaryjskiego.

Także w Karczewie place miejskie straciły swój tradycyjny, handlowy charakter. Świński Rynek całkowicie zniknął z przestrzeni miasta, zabudowany w latach 60. zespołem ratusza miejskiego oraz banku i komisariatu policji. Oddalenie ratusza od głównego 

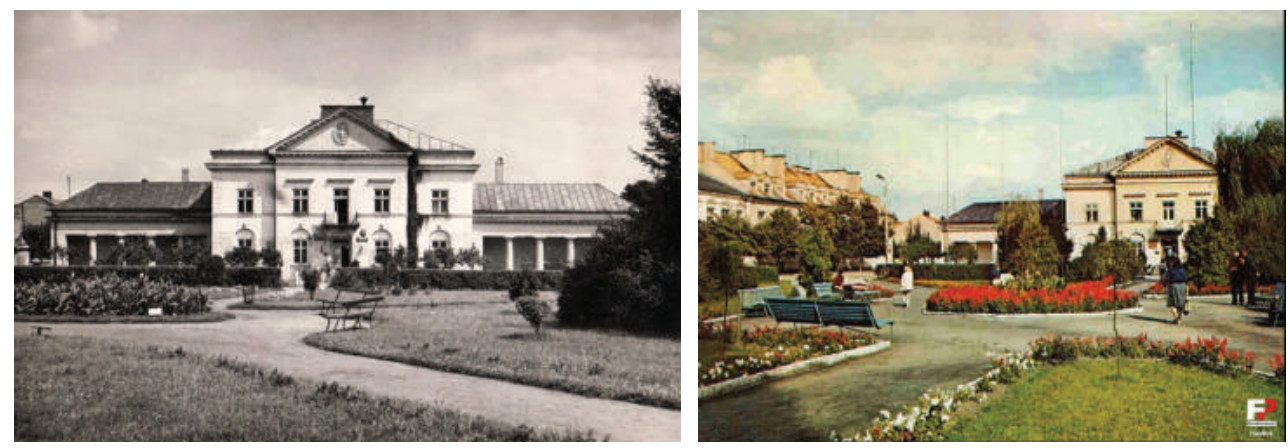

Ryc. 9., 10. Ratusz miejski w Górze Kalwarii lata 1965-70 oraz 1970-80 Źródło: Domena publiczna

placu miejskiego, o około 300 metrów, zmniejszyło znaczenie głównego placu miejskiego i częściowo relokowało funkcje centrotwórcze poza obszar centrum historycznego. Dodatkowo brak usług wzdłuż ul. Wiślanej łączącej ratusz z placem miejskim wpłynął negatywnie na rozbicie strefy centralnej miasta. Z kolei przedwojenny jeszcze podział rynku Zygmunta Starego na trzy części bryłą remizy strażackiej spowodował dalsze negatywne konsekwencje: część zachodnia placu przekształciła się $\mathrm{w}$ zieleniec. W zabudowie usytuowanej w pierzejach tej części placu zabrakło funkcji usługowych. Dodatkowo na północ od remizy powstały kolejne parterowe pawilony handlowe, wzmacniając dodatkowo niekorzystny przestrzenny podział placu, ale paradoksalnie przywracając częściowo historyczne funkcje na środku rynku. Jednakże profil usług w tych obiektach nie ma znaczenia ogólnomiejskiego (ryc. 11).

Funkcja targowa została częściowo utrzymana na przedlokacyjnym placu Starego Miasta, na wschód od Rynku Zygmunta Starego. W jego północno-wschodnim narożniku po dziś dzień funkcjonuje zespół straganów targowiska miejskiego. Pozostała część placu to jednakże zaplecze i otoczenie kościoła św. Wita, ogrodzone w znacznym stopniu i niedostępne ogółowi mieszkańców. W zachodniej części placu istnieje zespół przystanków autobusowych-pozostałość dawnego, głównego przystanku PKS-obecnie wykorzystywany wyłącznie przez linie autobusowe „przelotowo”. Zbędne jest zatem utrzymywanie tak dużej powierzchni wybetonowanej, zwłaszcza przy braku porządnych chodników w pierzei zachodniej placu.

\section{Nowe miasta}

Inaczej niż w miastach lokacyjnych, w miastach nowożytnych ich strefa centralna tworzyła się i definiowała dopiero w XX w. Do wybuchu wojny centrum Otwocka nie było wyraźnie wykształcone ze względu na specyficzny układ przestrzenny jego struktury, której wyraźnymi determinantami były $\mathrm{z}$ jednej strony uwarunkowania środowiska przyrodniczego, z drugiej linia kolejowa ze stacją Otwock i dwoma przystankami (Świder przy dolinie Świdra i Śródborów przy mieście-ogrodzie). Rozproszenie zabudowy 


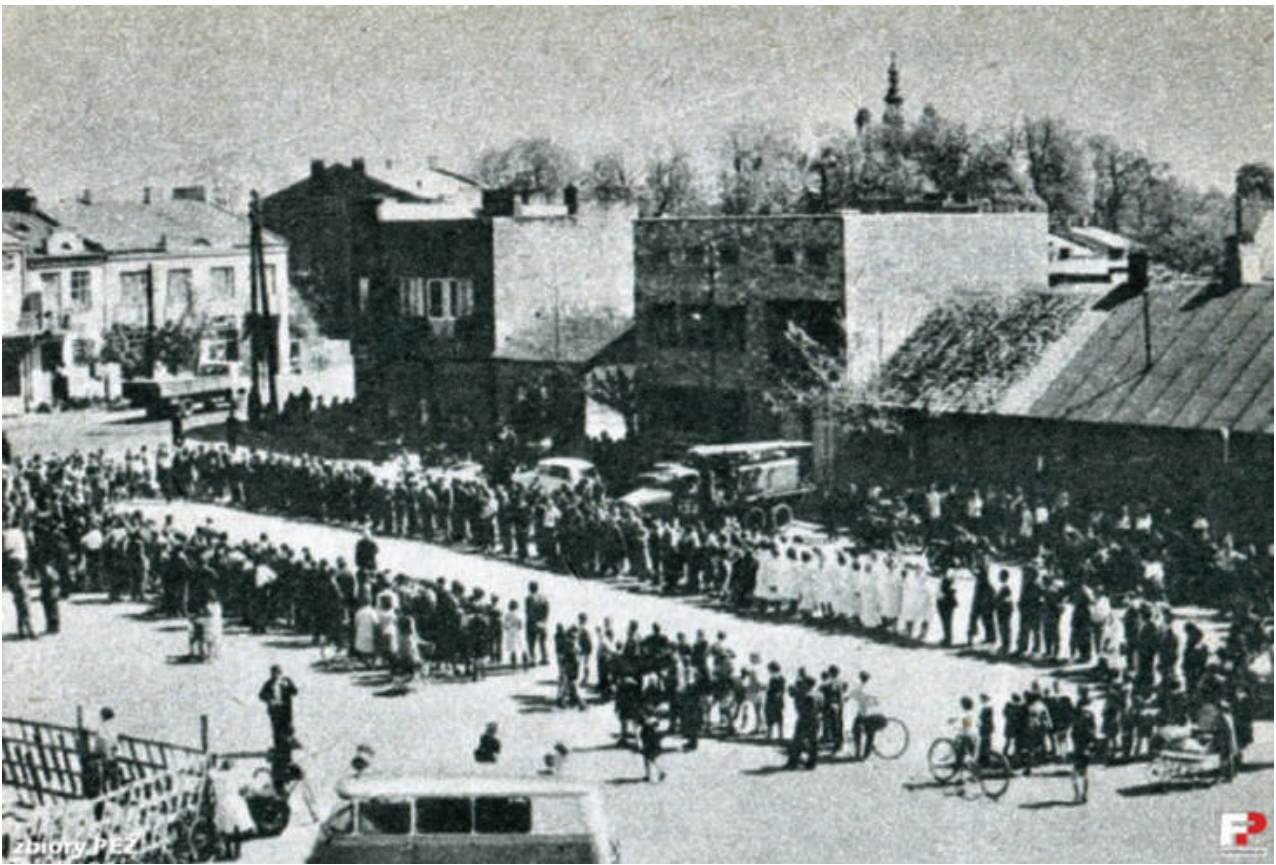

Ryc. 11. 1966, Karczew w 1966 r. “Omówienie zajęć Terenowych Oddziałów Samoobrony” Źródło: Tygodnik "W Służbie Ojczyzny", numer 8/66, Fot. M. Płowenc

spowodowało również dyspersję funkcji centrotwórczych z lekką koncentracją obiektów usługowych w rejonie stacji PKP.

Okres powojenny przyniósł miastu niekontrolowane przeobrażenia jego struktury społecznej i przestrzennej związane z przejęciem przez Otwock funkcji sypialni dla zniszczonej Warszawy. Napływ pierwszej fali migracyjnej ludności przedwojennej spowodował zasiedlanie pensjonatów, które tym samym przestały pełnić swą dotychczasową funkcję. W kolejnych latach zaczęły powstawać zespoły zabudowy dla osób zatrudnionych w sanatoriach, szpitalach, szkolnictwie, ośrodkach wypoczynkowych oraz dla zatrudnionych w zrealizowanym w Świerku Instytucie Energii Atomowej. Często były to zespoły zabudowy wielorodzinnej blokowej, miernej architektonicznie, degradujące charakterystyczny dla dawnego uzdrowiska krajobraz willi i pensjonatów, sytuowane na dużych zalesionych działkach. Dopuszczono też w Otwocku rozwój rzemiosła i drobnej wytwórczości; miasto pełniło również funkcję siedziby powiatu, co wiązało się z realizacją i utrzymaniem w nim właściwych instytucji administracji państwowej.

W rozrastającym się mieście, zwłaszcza w rejonie stacji kolejowej, Otwock od strony południowo-zachodniej i zachodniej zaczął przekształcać się w oczywisty sposób w zespół handlowo-usługowy. Jakość powstałej zabudowy jest wyjątkowo niska: przeważają tu obiekty parterowe, pawilonowe, typowe dla targowisk osiedlowych. Także sama nawierzchnia posadzki, zdewastowana ruchem samochodów dostawczych, nie zachęca do odwiedzania tego rejonu ani do dłuższego w nim przebywania. 
Wielość wprowadzonych funkcji sprawiła, że struktura funkcjonalno-przestrzenna miasta zaczęła się zamazywać; nastąpiła deformacja struktury miejskiej, w tym zwłaszcza centralnej strefy miasta, utrudniając racjonalną przestrzennie lokalizację ośrodka administracyjno-usługowego. Obiekty związane z realizacją funkcji obsługujących miasto i powiat są rozproszone, miasto nie ma ukształtowanego wyrazistego centrum usługowego.

Społecznie niepożądaną „wizytówką” centralnej części Otwocka jest wieka „dziura w ziemi" po rozpoczętej, niezrealizowanejbudowie galerii handlowejna placu Niepodległości. Plac przed dworcem kolejowym jest nieuporządkowany. Tymczasem jest to teren niezwykle eksponowany, bo zlokalizowany w bezpośredniej bliskości stacji PKP Otwock, u zbiegu najbardziej w mieście uczęszczanych ulic: Andriollego i Orlej. Paradoksalnie to na południe od tego obszaru, wzdłuż południowego odcinka ul. Andriollego, w parterach nowych budynków wielorodzinnych utworzył się jednostronnie wielkomiejski ciąg handlowy (ryc. 12).

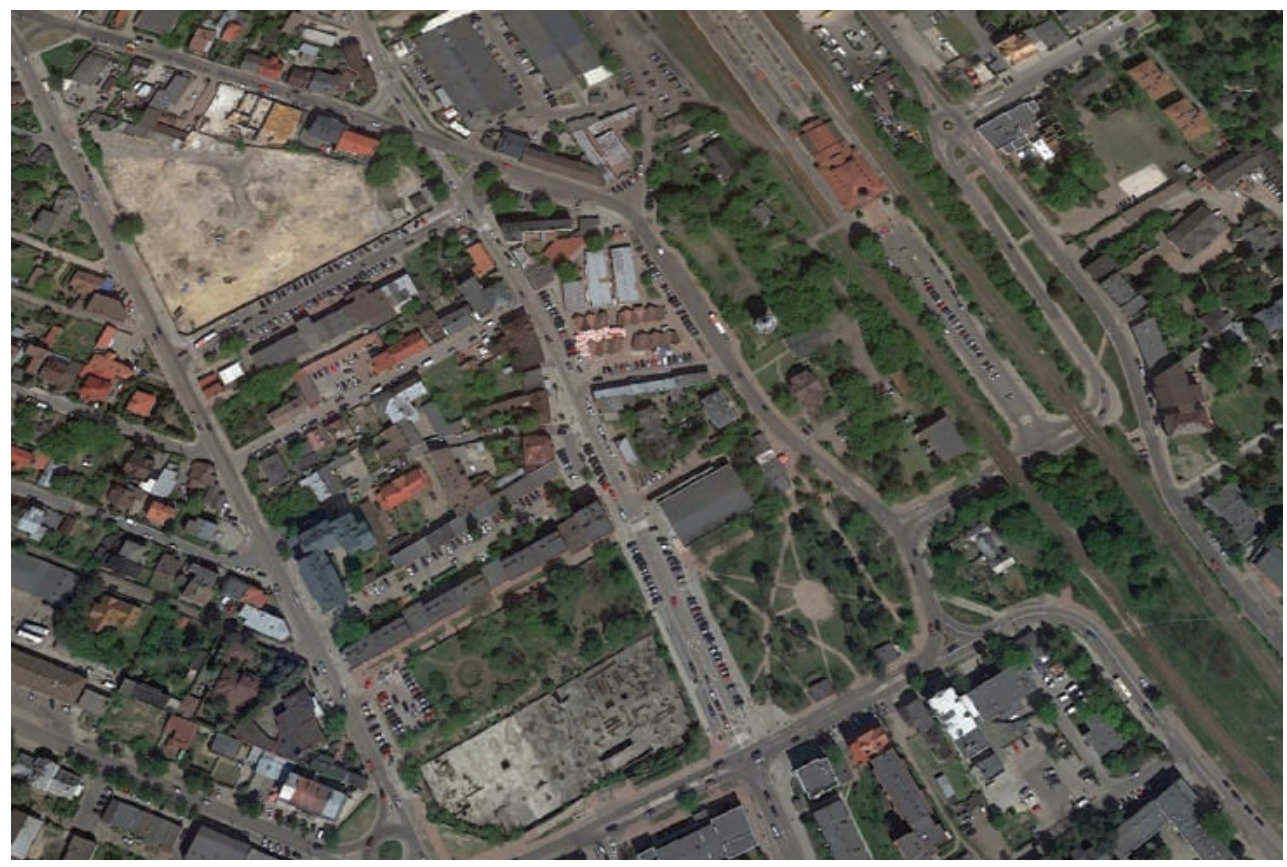

Ryc. 12. Obecny widok strefy centralnej Otwocka; widoczne zespoły bazarowisk i niedokończona budowa centrum handlowego Źródło: Google Maps

Rozwój Piastowa rozpoczął się dopiero w okresie powojennym. Już w 1945 r. powstały w nim dwie szkoły średnie. W 1952 r., osadzie liczącej 10 tysięcy mieszkańców nadano prawa miejskie. Od końca lat 50. rozpoczęto $\mathrm{w}$ mieście realizację zespołów spółdzielczej zabudowy mieszkaniowej wielorodzinnej, lokalizowanych głównie w północno-zachodniej części miasta. 
Centrum miejskie ukształtowało się pomiędzy rejonem osad kolejowych a stacją kolejowa, wzdłuż ul. 11 Listopada, na południe od stacji. W tym rejonie zrealizowano urząd miasta, pocztę, liceum ogólnokształcące oraz zespół szkół zawodowych. Także po północnej stronie stacji kolejowej ukształtował się niewielki zespół sklepów i punktów gastronomicznych, połączony $\mathrm{z}$ częścią południową podziemnym tunelem. Jednakże funkcje usługowe $\mathrm{w}$ mieście powiązane były często $\mathrm{z}$ terenami produkcyjnymi, jak chociażby Instytut Przemysłu Gumowego 'Stomil' i powstawały w przypadkowych lokalizacjach, poza strefą centralną miasta (ryc. 13).

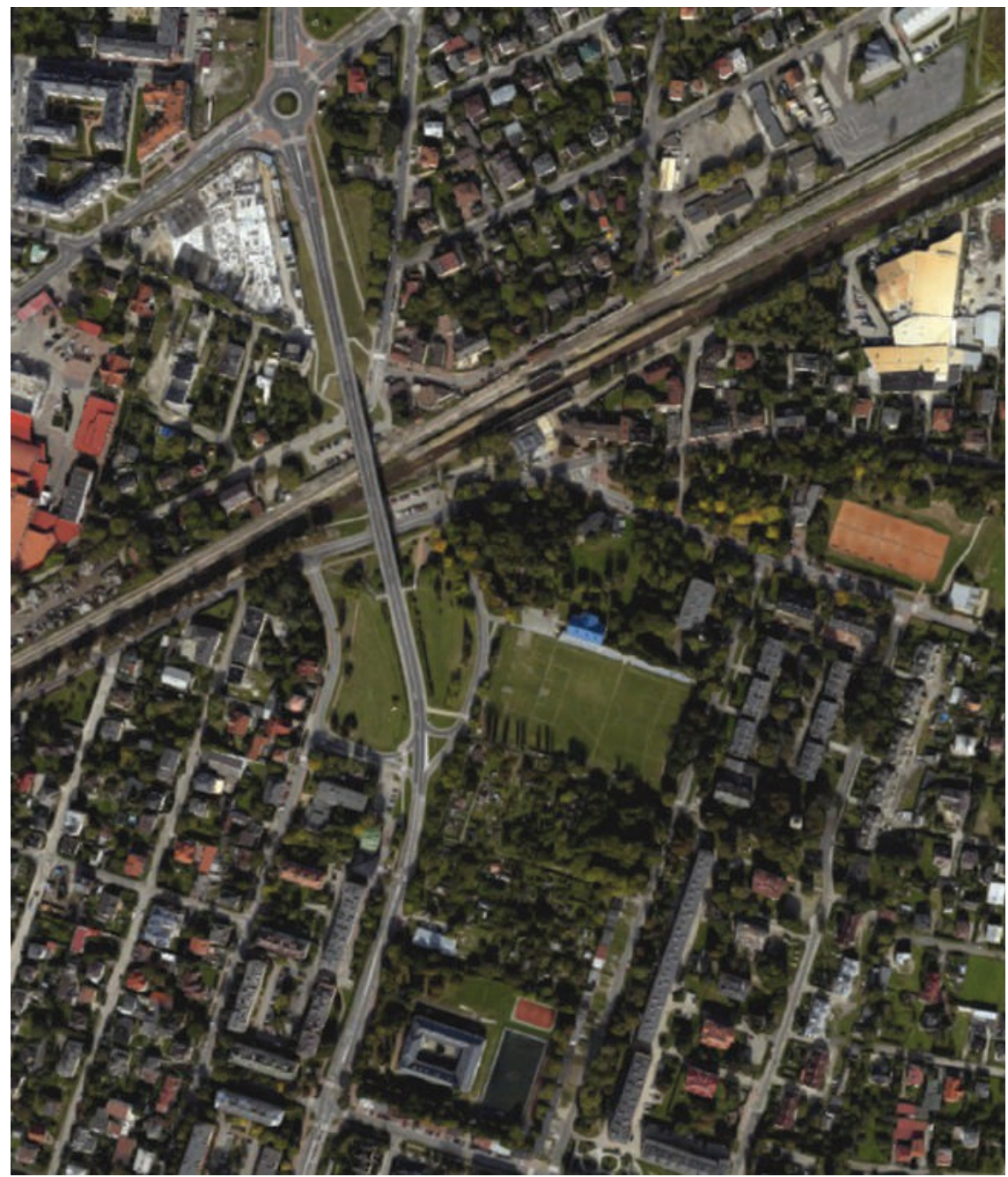

Ryc. 13. Obecny widok strefy centralnej Piastowa; widoczny wiadukt nad linią kolejową, ogrody działkowe w centrum miasta oraz fragmenty terenów produkcyjnych usytuowanych wzdłuż linii kolejowej Źródło: Google Maps 
Jeszcze pod koniec XX w. centrum Piastowa zostało rozdarte i ograniczone od zachodu wiaduktem drogowym nad linią kolejową łączącym część północną i południową miasta. Dodatkowo, tereny takiejak ogrody działkowe niweczą potencjał centrotwórczy stacji kolejowej.

\section{Problem zanikania historycznej, handlowej i reprezentacyjnej funkcji w strefach centralnych - problemy znalezienia nowych form ich zagospodarowania i włączenia w rozwijającą się tkankę miast. Możliwe działania ożywiające przestrzeń}

\section{Miasta lokacyjne}

Centra małych i średnich miast o genezie lokacyjnej to obszar, który w przypadku niedużych miast nadal powinien stanowić serce miasta, związane z głównymi działalnościami w mieście. Znalezienie sposobu na ożywienie tej przestrzeni to często główny bodziec do rozpoczęcia złożonego procesu porządkowania i planowego rozwoju centrum.

Niestety, w Górze Kalwarii nowe, istotne inwestycje z zakresu usług centrotwórczych powstawały na początku XXI w. w pewnym oddaleniu na północny zachód od centrum historycznego, wzdłuż ul. Pijarskiej, na jej odcinku „,szerokim”. Pewna relokacja funkcji centralnych wynika ze skomplikowanych uwarunkowań komunikacyjnych - historyczny odcinek ul. Pijarskiej jest wąskim gardłem, przez które przemieszcza się codziennie ruch tranzytowy pomiędzy Sandomierzem a Warszawą - liczne samochody ciężarowe skutecznie utrudniają mieszkańcom użytkowanie tej części miasta. Tworzące się korki zniechęcają do korzystania z przyległych usług. Sam hałas jest dodatkowo jedną z przyczyn unikania przestrzeni sąsiadującej z głównym placem miejskim. Podstawowym powodem pojawiania się mieszkańców w przestrzeni rynku jest zlokalizowany tutaj zespół przystanków autobusowych. Osoby dojeżdżające do pracy i do szkół w Górze Kalwarii z okolicznych miejscowości oczekują na placu na busy, ale potencjał centrotwórczy tego dworca nie jest właściwie wykorzystany (ryc. 14).

Szansą na przywrócenie mieszkańcom strefy centralnej miasta jest realizowana właśnie obwodnica Góry Kalwarii w śladzie dróg krajowych nr 79 i 50 [Maliszowa 1974]. Usunięcie tranzytu towarowego i częściowo osobowego z ul. Pijarskiej pozwoli na jej przebudowę do parametrów drogi gminnej/powiatowej, z węższą jezdnią parkingami przyulicznymi czy nową zielenią miejską w przestrzeni ulicy. Ułatwienie dostępu do usług w parterach budynków i przebudowa ulicy do parametrów miejskich, zamiast tranzytowych, powinna zachęcić mieszkańców do powrotu do głównej handlowej ulicy w rejonie historycznego centrum Góry Kalwarii.

Usunięcie uciążliwości tranzytu oraz przebudowa samej przestrzeni rynku, z wprowadzeniem elementów uatrakcyjniających przestrzeń, powinny skutkować powrotem mieszkańców do placu miejskiego.

Miasto zleciło opracowanie koncepcji modernizacji rynku oraz rozpoczęło dyskusję publiczną nad przedstawionymi wariantami. Uwagi mieszkańców skutkowały zachowaniem większej niż pierwotnie zakładano liczby drzew na placu, tworzących dwa wyraźne pasy 


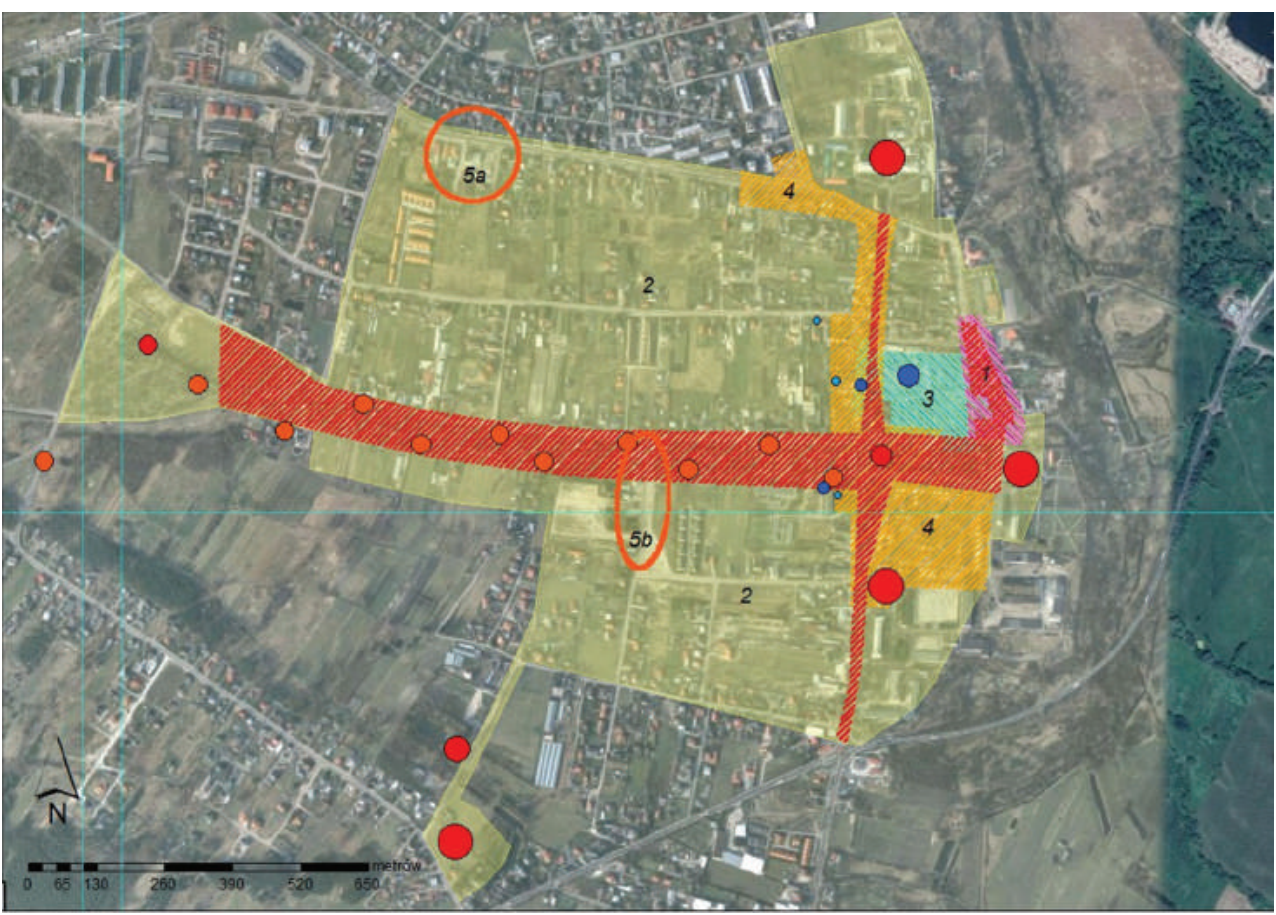

1 - najstarszy zespół przedlokacyjny

2 - obszar Nowej Jerozolimy - układ miasteczka kalwaryjskiego; historyczne: czerwony sztraf - główny układ przestrzeni publicznych założenia kalwaryjskiego; czerwone i pomarańczowe kropki - zgromadzenia, kościoły i kaplice układu kalwaryjskiego
3 - kwartały dzielnicy żydowskiej; niebieskie kropki - obiekty związane z religią i kulturą żydowską 4 - główny obszar z funkcjami centrotwórczymi w mieście

$5 a-$ istniejący zespół handlowy przy ul. Pijarskiej $5 \mathrm{~b}$ - relokowane z placu miejskiego targowisko miejskie

Ryc. 14. Obiekty i obszary centrotwórcze i miastotwórcze w Górze Kalwarii, $z$ podziałem na etapy powstawania Źródło: analiza własna arch. Izabeli Sobierajskiej na mapie wg Google Maps, na podstawie A. Kuncewicz, 1929, Plany przeglądowe miast polskich
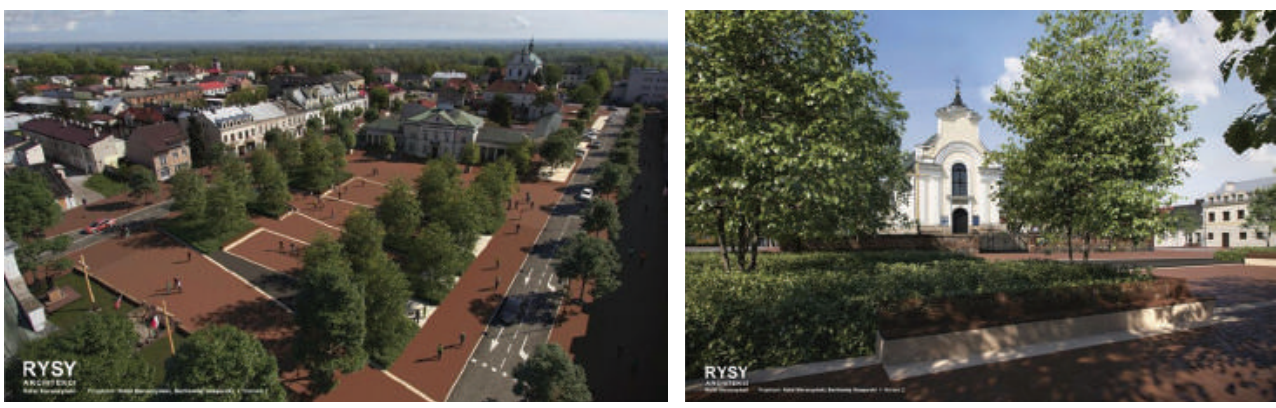

Ryc. 15., 16. Projekt modernizacji głównego placu miejskiego w Górze Kalwarii ; projekt: Rysy Architekci Źródło: http://piasecznonews.pl/czy-tak-bedzie-wygladal-kalwaryjski-rynek/ 
nasadzeń, podkreślające osiowość dawnego założenia kalwaryjskiego. W cieniu drzew i krzewów ustawiono liczne miejsca do siedzenia. Na wniosek mieszkańców umieszczono także w projekcie rozbudowane fontanny (ryc. 15, 16).

Jednakże wątpliwość budzi usunięcie z przestrzeni placu przystanków autobusowych oraz większości miejsc postojowych dla samochodów. Główny problem zamierania życia na placu, czyli brak lokali usługowych wokół niego w pierzejach zabudowy, nie został rozwiązany. Podobnie, projektowana modernizacja skweru ks. Sajny, położonego

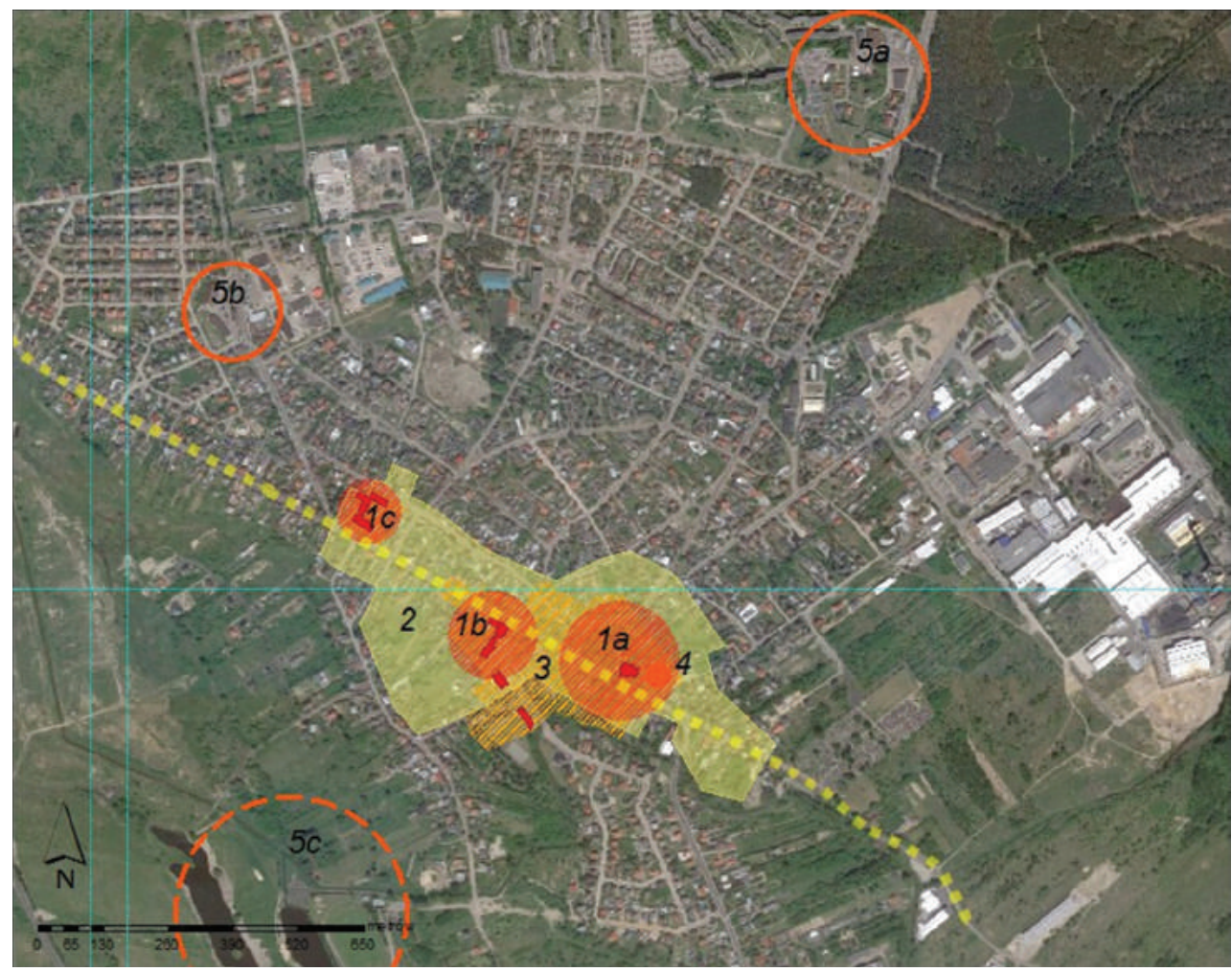

1 - najstarsze zespoły historyczne:

1 a - zespół przedlokacyjne, Stare miasto

1 b - zespół lokacyjny wokół renesansowego rynku Zygmunta Starego

1c - rejon nieistniejącego Świńskiego Targu, obecnie Urząd Gminy

2 - obszar zabudowy z przełomu XVIII i XIX w.:

3 - główny obszar z funkcjami centrotwórczymi w mieście
4 - zachowane targowisko na placu Starego Miasta $5 a$ - istniejący zespół handlowy przy granicy Karczewa i Otwocka, powstały w latach 60 dla obsługi osiedla wielorodzinnego Ługi, rozbudowany w ostatnich 20 latach

5b-nowy zespółhandlowy w północno-zachodniej części miasta

5c- projektowany zespół sportowo-rozrywkowy

Ryc. 17. Obiekty i obszary centrotwórcze w Karczewie, z podziałem na etapy powstawania Źródło: analiza własna arch. Izabeli Sobierajskiej na mapie wg Google Maps, na podstawie A. Kuncewicz, 1929, Plany przeglądowe miast polskich 
na północny wschód od głównego placu miejskiego, dotyczy jedynie nawierzchni tej przestrzeni. W Górze Kalwarii potrzebne są działania radykalniejsze, jak np. przywrócenie funkcji handlowej dawnych kramów.

W Karczewie największymi problemami funkcjonalnymi centralnej, historycznej strefy miasta są: podział placu bryłą remizy strażackiej i oddalenie ratusza od placu, a także tranzyt samochodowy przechodzący przez system placów miejskich Starego Miasta i Rynku Zygmunta Starego. Nie bez wpływu na dysfunkcyjność historycznego centrum jest także relokacja ogólnomiejskich funkcji w rejon północny i północno-zachodni miasta, gdzie powstały zespoły obiektów handlowych (ryc. 17) [Sobierajska, Sikorska 2016].

Ruch samochodów ciężarowych przez centrum Karczewa wynika z faktu, iż dzielnica produkcyjna położona jest w północno-wschodniej części miasta, a obwodnica drogi wojewódzkiej obiega miasto od południowego zachodu i dawny, historyczny szlak ul. Wiślanej jest najlepszym i de facto jedynym połączeniem komunikacyjnym tych elementów. Szansą na likwidację ruchu ciężarowego przez środek miasta będzie realizacja zewnętrznego powiązania dzielnicy produkcyjnej z drogą wojewódzką nr 801 [Maliszowa 1974].

Eliminacja ciężkiego ruchu samochodowego, który zdominował centralną część miasta i zdestabilizował jej funkcjonowanie, utrudniając dostęp do przestrzeni tradycyjnych placów i obiektów publicznych, umożliwi ich odzyskanie i aktywizację poprzez wprowadzenie funkcji usługowych, rekreacyjnych i reprezentacyjnych oraz poprzez dostosowanie ich do potrzeb i wymogów współczesności. Ten kierunek działań dobrze ilustrują projekty rewitalizacji przestrzeni placu Zygmunta Starego i placu Starego Miasta autorstwa arch. Joanny Wójcik. Główną ideą projektu dla Placu Zygmunta Starego jest generalne utrzymanie wykształconego funkcjonalnego podziału placu. Przekształcenia objęły przede wszystkim układ jezdni, zaproponowano też relokację stref parkingowych. Przesunięcie jezdni spod pierzei wschodniej w kierunku remizy pozwoli na uzyskanie poprawnego skrzyżowania z ulicą wybiegającą na północ od placu, oraz stworzy możliwości ukształtowania się funkcji reprezentacyjnych we wschodniej jego części. Z kolei przesunięcie i obrócenie pomnika upamiętniającego poległych karczewian w części północnej, stworzy przed tym pomnikiem od wschodu przestrzeń pozwalającą bezpiecznie organizować uroczystości rocznicowe (ryc. 18, 19).
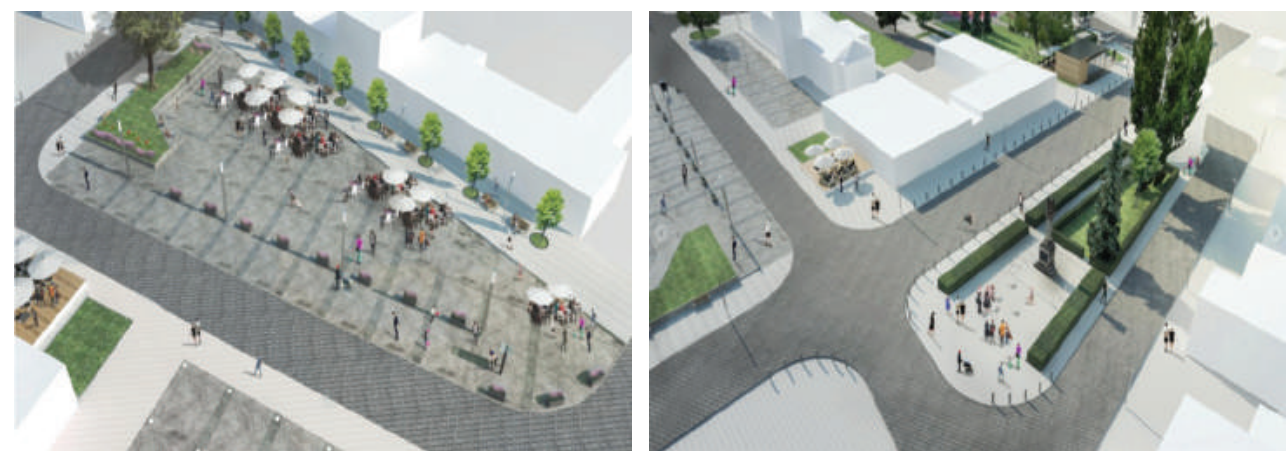

Ryc. 18., 19. Karczew - projekt rewitalizacji placu Zygmunta Starego, proj. arch. Joanna Wójcik Źródło: arch. Joanna Wójcik 
W rejonie zachodnim placu utrzymano funkcję rekreacyjna, z usunięciem części zbyt rozrośniętych wysokich drzew. Na nowo zakomponowano układ alejek spacerowych, wprowadzono nowoczesny plac zabaw dla dzieci. Wzdłuż ulic relokowano część programu parkingowego z rejonu wschodniego placu. Plac parkingowy powstał także na zapleczu remizy, oddzielony zielenią od terenu rekreacyjnego (ryc. 20, 21).
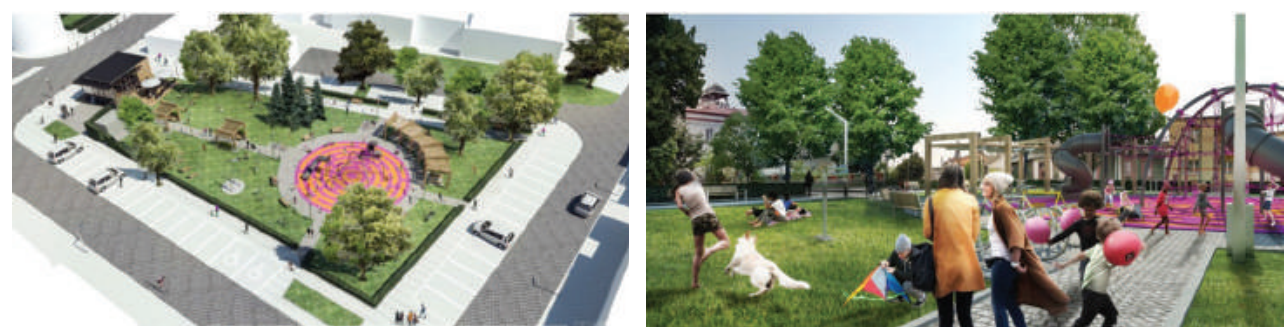

Ryc. 20., 21. Karczew - projekt rewitalizacji placu Zygmunta Starego, rejon zachodni placu - część rekreacyjno-parkowa, proj. arch. Joanna Wójcik Źródło: arch. Joanna Wójcik

Projekt dla rynku Starego Miasta dotyczy części targowiska - jego uporządkowania w nowej oprawie architektonicznej drewnianych zadaszeń z detalem zaczerpniętym ze stylu Świdermajer (ryc. 22).

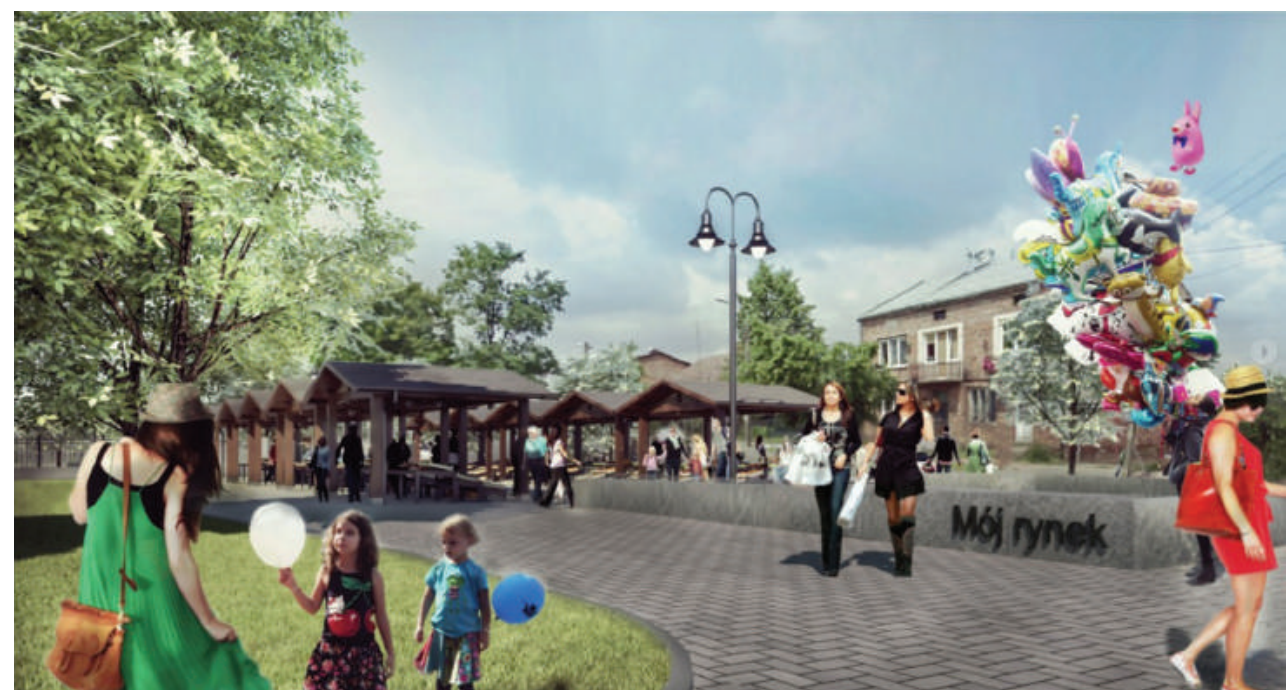

Ryc. 22. Karczew - projekt rewitalizacji placu Starego Miasta, proj. arch. Joanna Wójcik Źródło: arch. Joanna Wójcik 


\section{Nowe miasta}

Przełom XX i XXI w. w miastach „nowych” to kolejny etap przemian. Mieszkańcy tych miast i ich włodarze zdają sobie sprawę z roli, jaką powinny one odgrywać jako lokalne centra organizujące jakość życia nie tylko społeczności miasta, ale i ludności mieszkającej w strefie ich obsługi.

W strukturze przestrzennej centralnej części miasta Otwocka istotnym problemem jest jej amorficzność, rozproszenie obiektów realizujących funkcje administracyjno- usługowe, ale także zacieranie historii urbanistyczno-architektonicznej zmaterializowanej $\mathrm{w}$ siatce ulic i zachowanych budynkach o wysokich walorach kulturowych. Podejmowane są próby wykreowania wyrazistego, reprezentacyjnego centrum na podstawie zasad rozwoju strefy śródmiejskiej zapisanych w z SUiKZP m. Otwocka [Studium... 2014]: „rozwój centrum miasta; likwidacja chaotycznej zdegradowanej zabudowy; dyslokacja z tego obszaru funkcji niezgodnych z wiodącymi funkcjami centrum; modernizacja przestrzeni publicznych szczególnie placu przed zabytkowym dworcem, terenów zieleni i pasaży handlowych; uporządkowanie układu komunikacyjnego; rozwiązanie problemu parkowania poprzez realizacje podziemnego parkingu i wyznaczenie strefy ograniczonego parkowania" (ryc. 23).

Studium wskazuje lokalizację miejskiego centrum w rejonie dworca kolejowego Otwock, w większej części planowane do wytworzenia po jego stronie zachodniej, w mniejszym stopniu po stronie wschodniej.

Interesujące spojrzenie na zagadnienie racjonalnego, wpisanego w tradycję miasta kształtowania jego centrum przedstawia praca magisterska Marty Sidoruk-Gościckiej [Maliszowa1974; Sidoruk-Gościcka 2014]. Główny teren centralnej części Otwocka - Rynek przy Orlej, położony na południowy zachód od stacji kolejowej, staje się reprezentacyjną przestrzenią publiczną. Jej oprawę tworzą eksponowane i wskazane do restauracji zabytkowe budynki definiujące otwocki klimat architektoniczny, oraz nowa, przebudowywana i modernizowana zabudowa respektująca skalę, proporcje i detal architektoniczny otwockiej architektury. Zagospodarowanie terenu nawiązuje do tradycyjnych rozwiązań, widocznych na starych fotografiach ubiegłego wieku. Autorka zakłada uczytelnienie pierzei Rynku poprzez plombowe uzupełnienia, nadbudowy, przebudowy, odbudowy istniejących kamienic, ich remonty i rewaloryzację, założenie osi widokowych, wyeksponowanie i odsłonięcie dominant, obiektów atrakcyjnych i historycznych (np. dworzec PKP, wieża ciśnień, neogotycki obiekt, historyczne kamienice, budynki drewniane, charakterystyczne dla otwockiej architektury) (ryc. 24, 25).

Wyeksponowanie przestrzeni widokowych na najciekawsze w otoczeniu obiekty, to jeden z najważniejszych aspektów tej propozycji. Projektowane założenie zakłada otwarcie widoku na rynek i wieżę z peronów stacji kolejowej i przejeżdżających pociągów, jak również otwarcie widoku na zabytkowy budynek stacji od strony rynku. 


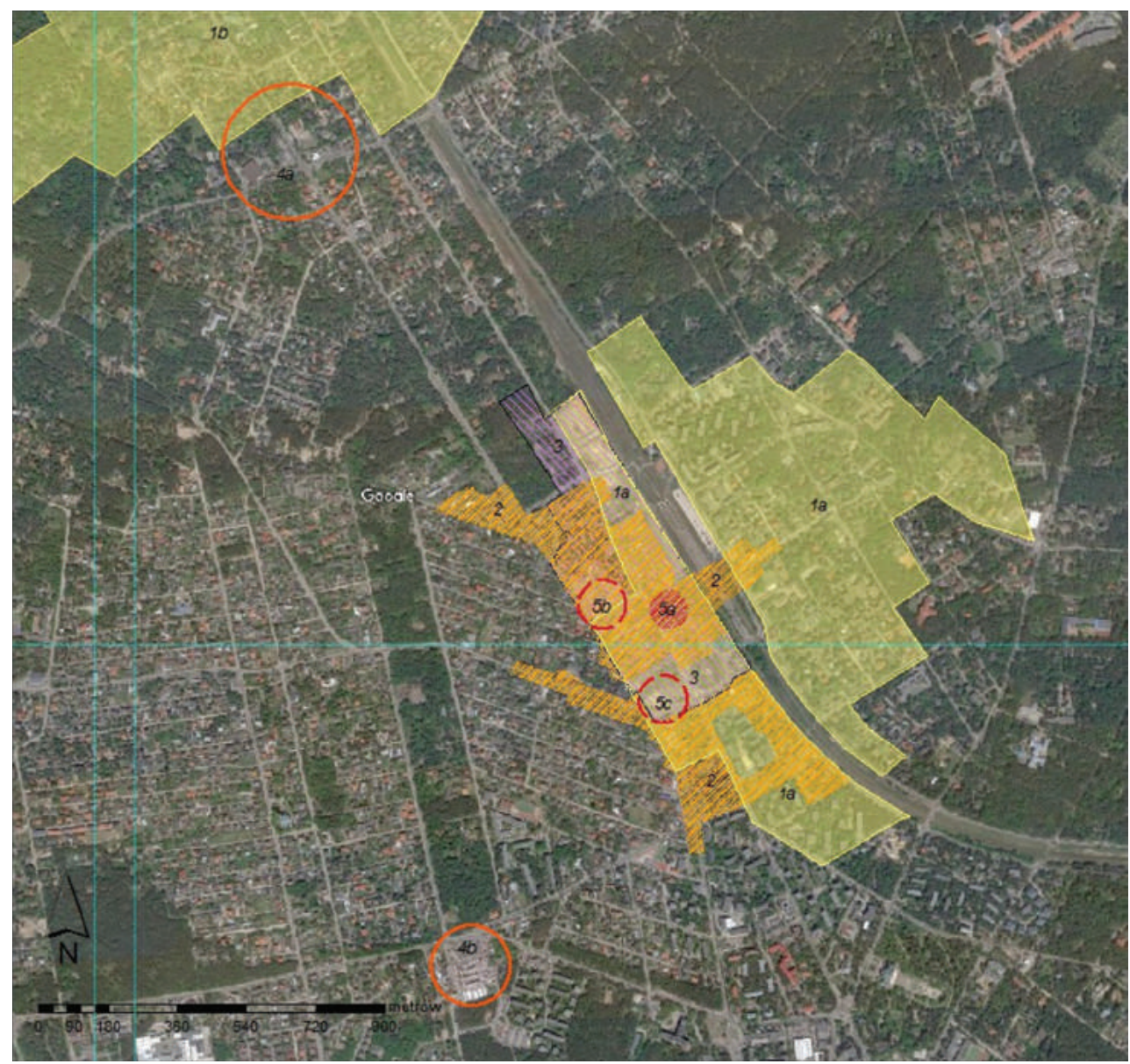

1 - najstarsze zespoły osadnicze:

$1 \mathrm{a}$ - rejon dawnych willi i pensjonatów w centrum Otwocka

$1 \mathrm{~b}$ - rejon dawnych willi i pensjonatów w Świdrze 2 - główny obszar z funkcjami centrotwórczymi w mieście

3 - obszar zdegradowanej i substandardowej zabudowy w obszarze centrotwórczym i w jego najbliższym sąsiedztwie
$4 a$ - istniejący zespół centralny w Świdrze

$4 \mathrm{~b}$ - bazar miejski

$5 a$ - rejon projektowane placu miejskiego na przedpolu droca kolejowego

$5 \mathrm{~b}$ - centrum handlowe $w$ trakcie realizacji $5 c$-centrum handlowe w trakcie realizacji, opóźniona i częściowo porzucona inwestycja, tzw. „dziura w ziemi”

Ryc. 23. Obiekty i obszary centrotwórcze i miastotwórcze w Otwocku, z podziałem na etapy powstawania Źródło: analiza własna arch. Izabeli Sobierajskiej na mapie wg Google Maps, na podstawie

A. Kuncewicz, 1929, Plany przeglądowe miast polskich 


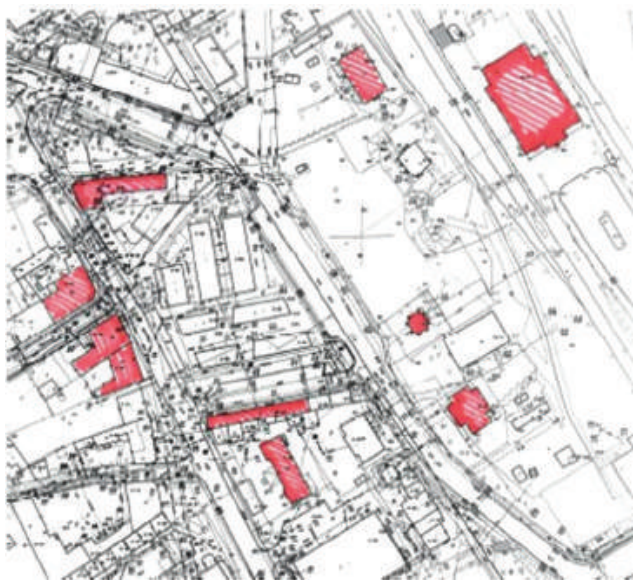

Ryc. 24. Zachowane obiekty o wartościach historycznych

Źródło: rysunek koncepcyjny, opracowanie M.Sidoruk-Gościcka, 2014

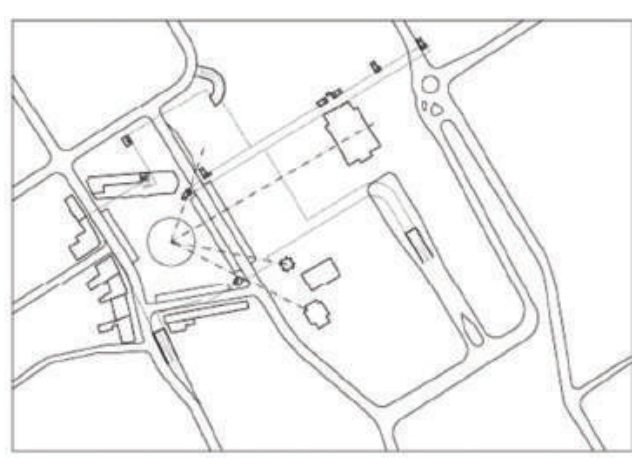

Ryc. 26. Koncepcja poprawy obsługi komunikacyjnej z systemem przejść podziemnych i lokalizacją podziemnego parkingu Źródło: opracowanie M.Sidoruk-Gościcka, 2014

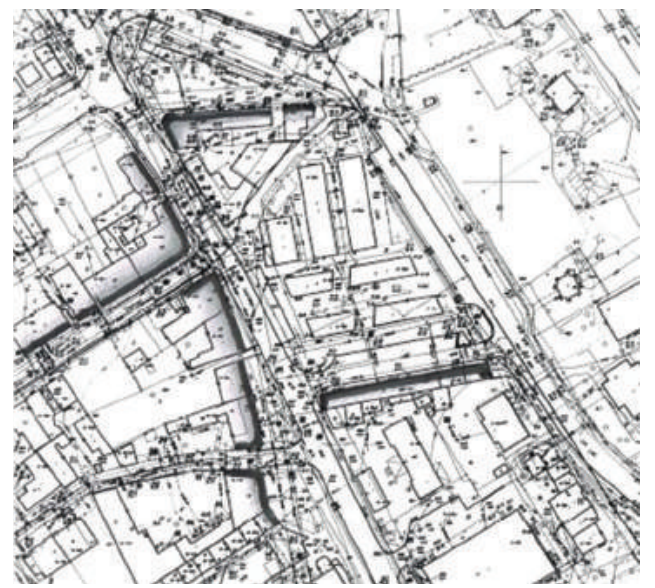

Ryc. 25. Uczytelnienie pierzei Rynku Źródło: rysunek koncepcyjny, opracowanie M.Sidoruk-Gościcka, 2014

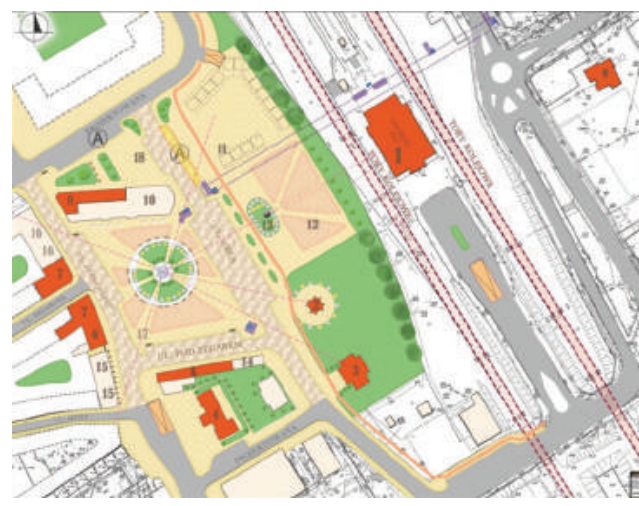

Ryc. 27. Projekt zagospodarowania centralnej części Otwocka - rynku przy ulicy Orlej Źródło: opracowanie M.Sidoruk-Gościcka, 2014

Plac rynku został zaprojektowany jako kameralna przestrzeń publiczna z centralnym klombem wokół fontanny zlokalizowanej na osi zabytkowego budynku dworca PKP, z systemem ciągów pieszych powiązanych z wyjściami z przejść podziemnych, zapewniających bezkolizyjne połączenie rynku z peronami i przestrzenią ulicy Kościelnej stanowiącej główny element krystalizujący części centrum położonej po wschodniej stronie torów kolejowych - oraz z wyjściami z zaprojektowanego garażu podziemnego radykalnie poprawiającego warunki parkowania w centrum miasta (ryc. 26, 27).

Bardziej intensywne w zakresie wprowadzanej zabudowy i programów podejście do kształtowania centralnej części Otwocka przedstawia opracowanie magisterskie Ewy Kurdej [Kurdej 2011]. 
Autorka kreuje centrum, jako miejsce największej koncentracji wielobranżowych funkcji usługowych, aby przyciągnąć nie tylko mieszkańców, ale również gości spoza miasta. Kształtuje zespół zabudowy usługowej w kwartale przestrzeni rynkowej przy ul. Orlej, budując mocną pierzeję dla placu na przedpolu dworca kolejowego.

Zaniedbane budynki zabytkowe oraz obiekty o wysokiej wartości kulturowej eksponuje w celu promocji unikatowej tradycji architektonicznej miasta. Proponuje zrealizowanie bezkolizyjnego przejścia podziemnego łączącego pasażem handlowo-usługowym ulicę Kościelną z dworcem kolejowym, a dalej poprzez plac miejski ze skwerem VII Pułku Łączności. Takie rozwiązanie usprawni ruch pieszy i pozwoli złączyć rozdzielone linią kolejową miasto. Włączenie w strefę centrum wschodniej części miasta, ukształtowanej na kanwie-zwieńczonej bryłą kościoła - ulicy Kościelnej jest istotnym walorem koncepcji (ryc. 28).

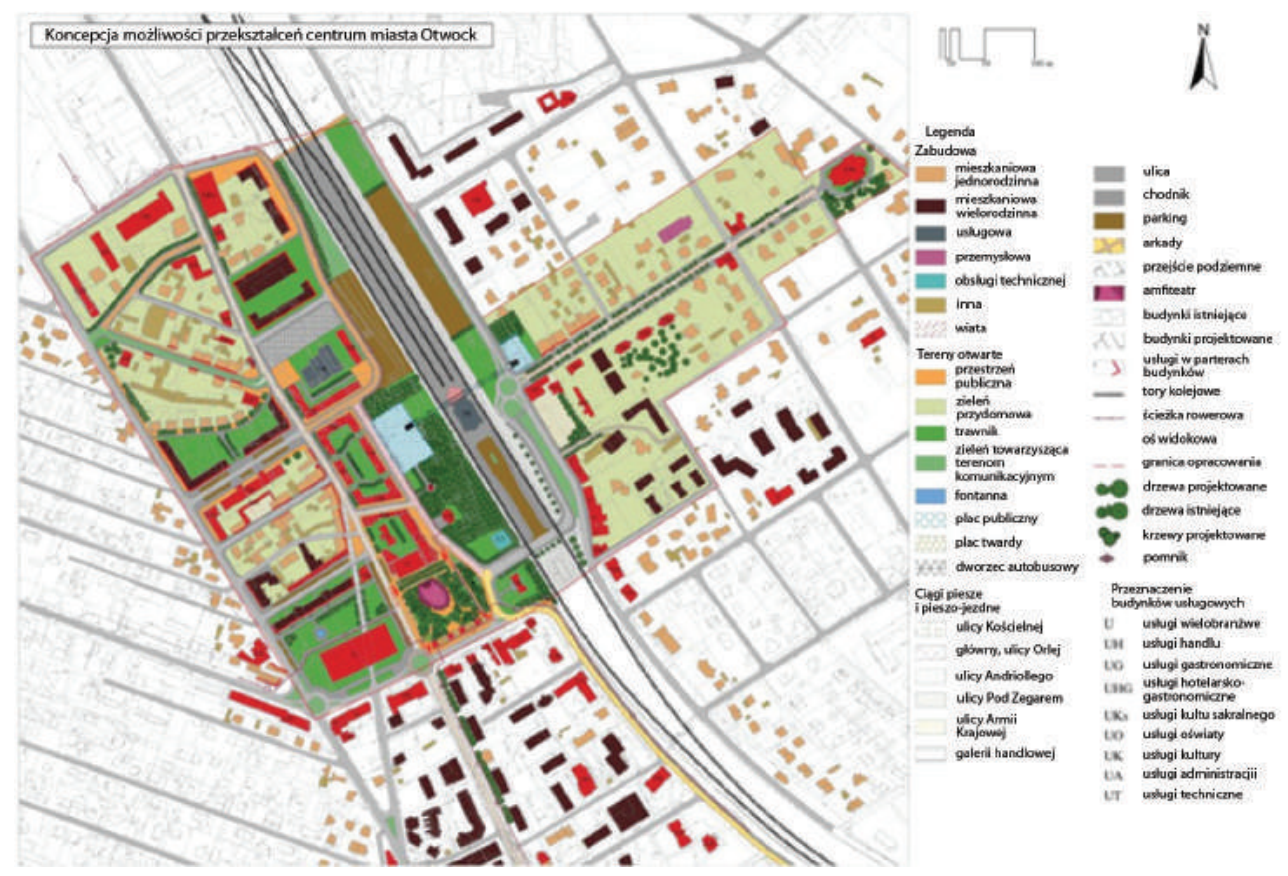

Ryc. 28. Koncepcja przekształceń centrum Otwocka Źródło: opracowanie E. Kurdej, 2011

Kształtowanie przestrzeni publicznych to kolejny, ważny aspekt opracowania. Oprócz wykreowania ul. Kościelnej jako ciągu pieszo-jezdnego, wzdłuż którego w parterach willi w stylu „świdermajer” zlokalizowano funkcje usług kultury i gastronomii, projekt zakłada wytworzenie ciągu pieszego w śladzie ulicy Orlej, na odcinku od ul. Świderskiej do ul. Powstańców Śląskich. 
Kolejne ulice przekształcone w ciągi pieszo-jezdne to: ul. Pod Zegarem, naprowadzająca na budynek wieży Ciśnień adaptowany na funkcje gastronomiczne i informacji turystycznej, ul. Andriollego spinająca północną i południową część centrum, ukształtowana w formie alei obsadzonej drzewami oraz północny odcinek ul. Armii Krajowej skupiający wiele ważnych instytucji miejskich takich jak: budynek Urzędu Miasta, teatr im. S. Jaracza, Sąd Rejonowy czy banki i usługi miejskie. Zadaniem projektowanego ciągu jest zbliżenie wymienionych instytucji do centrum Otwocka.

Istotną rolę $\mathrm{w}$ zarządzaniu rozwojem przestrzennych struktur miejskich, $\mathrm{w}$ tym ich centralnych części, odgrywa samorząd terytorialny. Podstawowym narzędziem jego działań w tym zakresie są miejscowe plany zagospodarowania przestrzennego. Dla centralnej części Otwocka w 2017 r. opracowany został projekt planu miejscowego „Centrum” [Sobierajska 2017], w którym wskazano przestrzeń dla realizacji placu miejskiego w rejonie zachodniego przedpola dworca kolejowego. Przestrzeń publiczną wskazano w miejscu obecnego targowiska miejskiego, tereny wokół niej, zdefiniowane zwartą zabudowa przeznaczono na funkcje usługowe i mieszkaniowo-usługowe (ryc. 29).

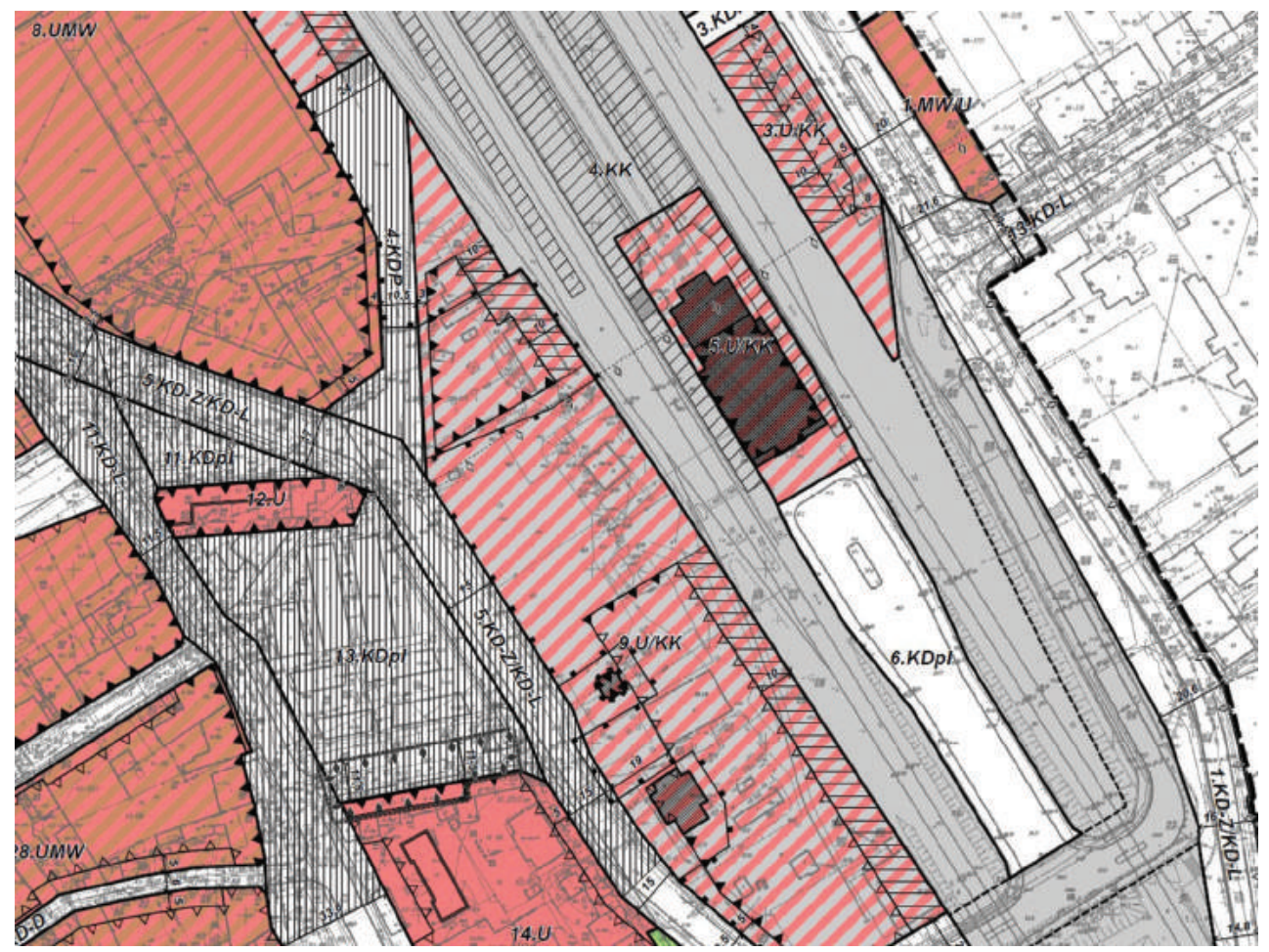

Ryc. 29. Mpzp dla rejonu centrum w Otwocku

Źródło: gł. projektant arch. Izabela Sobierajska; widoczne kształtowanie placu (13.KDpl) wg koncepcji M. Sidoruk-Gościckiej, 2014 
Problemem pozostaje jednak brak powiązania terenów centrum po wschodniej i zachodniej stronie linii kolejowej. PKP rozpoczęło przebudowę dworca Otwock na potrzeby obsługi pociągów dalekobieżnych, ale przebudowa ta nie uwzględnia realizacji tego, tak potrzebnego łącznika. Drugim, istotnym problemem jest znaczne obciążenie układu drogowego samochodami osobowymi. Zorganizowanie systemu komunikacji publicznej, dobrze obsługującej centralne tereny miasta, uwolniłoby ciągi uliczne od ogromnej liczby samochodów oddając je pieszym, humanizując ich przestrzeń, ale nie jest to już kompetencja planu miejscowego. Projekt planu wskazuje przestrzenie uliczne w centrum do szczególnego zagospodarowania, ale realność tego ustalenia wiązać się będzie z uwolnieniem ich od parkujących w centrum samochodów.

W Piastowie strefa centrum miejskiego nadal nie jest ostatecznie zdefiniowana. Zespół administracyjno-sportowy z częścią handlową funkcjonuje na południe od stacji kolejowej, rozciągając się ku południowi wzdłuż Alei Tysiąclecia, biegnącejna osi północ południe. Układ ten kończy się na południowej granicy miasta zespołem centrum handlowego. Na północ od stacji kolejowej istnieje niewielki zespół handlowo-gastronomiczny z towarzyszącym mu miejskim targowiskiem. Ten ostatni zespół jest właśnie modernizowany.

Po stronie północno-zachodniej od stacji powstał najnowszy zespół uzupełniający funkcje centrum - osiedla wielorodzinne z parterami usługowymi, przyciągającymi mieszkańców znacznej części miasta.

Jednak Piastów, miasto o jednym z najwyższych wskaźników gęstości zaludnienia w Polsce, swojego, z prawdziwego zdarzenia centrum, nie posiada. Nadal w strefie o największym potencjale centrotwórczym straszą ogrody działkowe, niedostępne dla ogółu mieszkańców, o miernym wyglądzie. Położony na północ od nich, a więc w bezpośrednim sąsiedztwie stacji kolejowej stadion MOSiR, ogrodzony solidnym płotem, także nie należy do przestrzeni reprezentacyjnych czy ogólnodostępnych. Oba te zespoły powinny być zastąpione funkcjami ogólnomiejskich usług: boisko mogłaby zastąpić hala sportowo-widowiskowa, miejsce ogródków powinny zająć albo obiekty usługowe z towarzyszącą zielenią albo nawet zabudowa wielorodzinna $\mathrm{z}$ rozbudowanym programem usługowym, z wykształconym systemem zieleni publicznej, powiązanej z parkiem miejskim przy stacji (ryc. 30). 


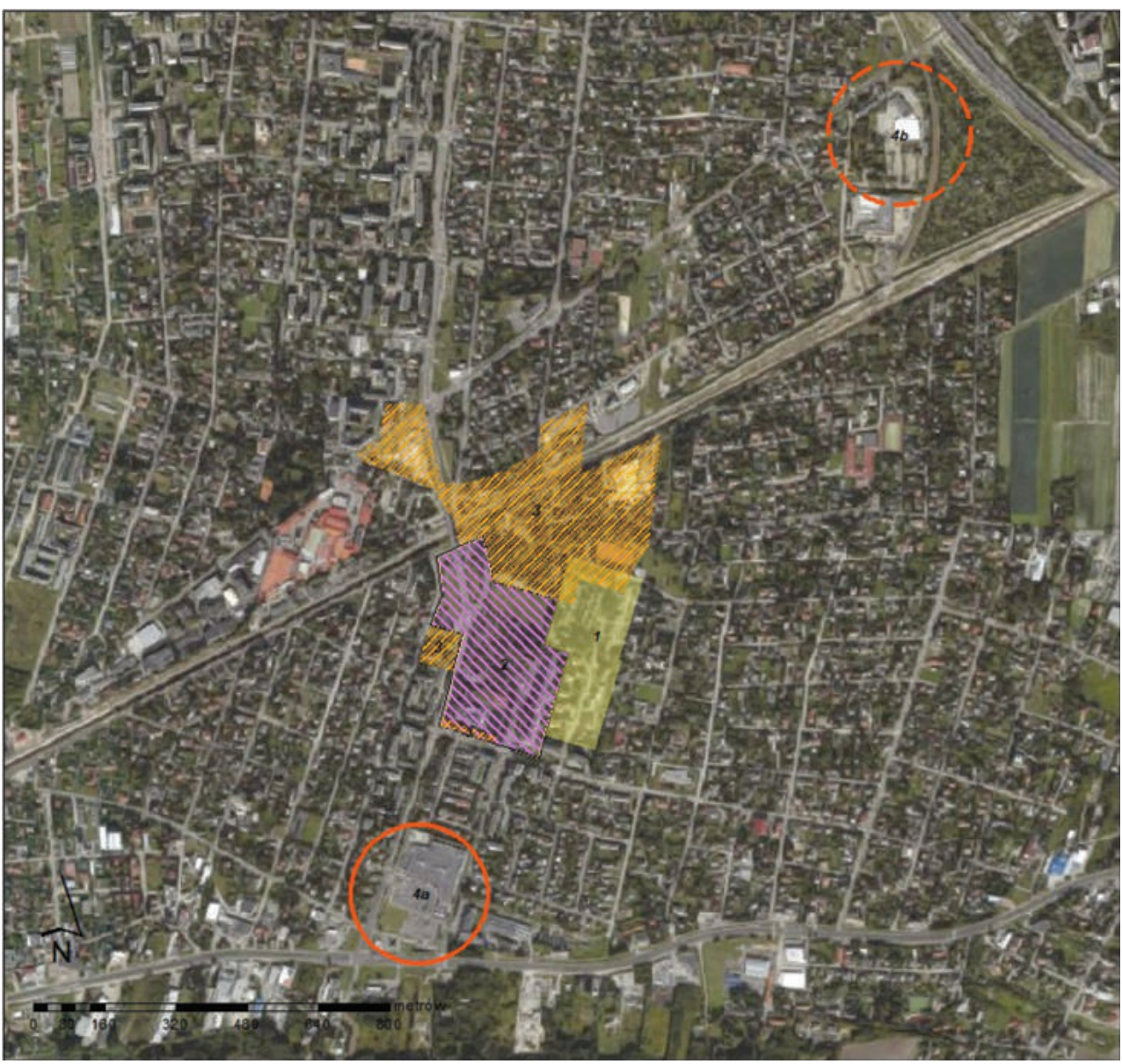

1 - najstarszy zespół z początku XX w. 2 -tereny w strefie centralnej ofunkcjach nieadekwatnych do rangi miejsca
3 - główny obszar z funkcjami centrotwórczymi w mieście

4a - istniejący zespół handlowy przy al. Tysiąclecia $4 \mathrm{~b}$ - projektowany zespół handlowo-usługowy

Ryc. 30. Obiekty i obszary centrotwórcze oraz miastotwórcze w Piastowie, z podziałem na etapy powstawania

Źródło: analiza własna arch. Izabeli Sobierajskiej na mapie wg Google Maps 


\section{Podsumowanie}

Na kształtowanie stref centralnych małych i średnich miast znaczący wpływ ma rola, jaką pełnią one wobec otaczających je obszarów, dla których z reguły są ważnymi centrami obsługi. Wywołuje to presję na lokalizowanie w nich funkcji administracyjno-usługowych.

O wyborze lokalizacji decyduje w przeważającej mierze kryterium dostępności inwestycyjnej terenu, co skutkuje zamieraniem historycznie ukształtowanych centrów, które, ze względu na „drobnoskalarną” strukturę architektoniczną zabudowy, nie mogą przyjąć obiektów o rozbudowanych programach.

Kolejnym czynnikiem, wyłączającym z aktywności tradycyjne strefy śródmiejskie, są przebiegające przez ich tereny drogi o charakterze tranzytowym, których uciążliwość ogranicza dostępność i tym samym zniechęca do korzystania z usług tam zlokalizowanych. Zjawiskiem nagminnym staje się zanikanie historycznych, handlowych i reprezentacyjnych funkcji w rejonach centralnych, lokalizowanie ich w nawiązaniu do kierunków rozwoju przestrzennego miasta.

Historycznie ukształtowane centra wymagają rewitalizacji, podjęcia działań humanizujących ich przestrzeń: ograniczenia ruchu kołowego, wprowadzenia zagospodarowania atrakcyjnego pod względem programowym i estetycznym; takie działania są projektowane i podejmowane przez lokalne samorządy.

W miastach nowych, których historia powstania wiąże się z realizacją stacji kolejowych, proces kształtowania się centrum nie jest ukończony. Na terenach przykolejowych, które miały w większości charakter przemysłowo-składowy i techniczny trwa stopniowa wymiana zagospodarowania; stwarza to szansę na ukształtowanie zagospodarowania spinającego charakterystyczne dla tego typu miast rozproszone funkcje centrotwórcze, przez stworzenie spójnego systemu przestrzeni publicznych obudowanego atrakcyjnymi programami [Lorens, Martyniuk-Pęczek (red.) 2010].

\section{Literatura}

Adamczewska-Wejchert H., Wejchert K., 1986, Małe miasta-problemy urbanistyczne, Arkady, Warszawa.

Bobko M., 2013, Przestrzenie publiczne miast współczesnych, Instytut Historii Sztuki, Uniwersytet Wrocławski, Wrocław.

Borkowska M. OSB, 2002, Dzieje Góry Kalwarii, Instytut Wydawniczy Księży Misjonarzy „Nasza Przeszłość”, Kraków.

Gawryluk D., 2012, Budowa obwodnic szansa na odzyskanie rynków przez małe miasta (Ostrów Mazowiecka, Zambrów, Grajewo), Czasopismo Techniczne. Architektura, Wydawnictwo Politechniki Krakowskiej im. Tadeusza Kościuszki, Kraków. 
Kuncewicz A., 1929, Plany przegladowe miast polskich, Zakład Architektury Polskiej, Politechnika Warszawska, Warszawa.

Kurdej E., 2011, Możliwości przekształceń funkcjonalno-przestrzennych i programowych centrum miasta Otwocka, praca magisterska. Promotor dr arch. M.E. Sikorska, Wydz. Geodezji i Kartografii, Politechnika Warszawska, Warszawa.

Lorens P., Martyniuk-Pęczek J. (red.), 2010, Problemy kształtowania przestrzeni publicznych, Wydawnictwo Urbanista, Gdańsk.

Maliszowa D., 1974, Śródmieście, Arkady, Warszawa.

Mława, 1885, [w:] B. Chlebowski, W. Walewski, F. Sulimierski (red.), Słownik Geograficzny Królestwa Polskiego i innych krajów słowiańskich, t. 6, Malczyce-Netreba, Warszawa.

Nowakowski M., 1990, Centrum miasta, Arkady, Warszawa.

Pazyra S., 1959, Geneza i rozwój miast mazowieckich, PWN, Warszawa.

Podhorecki L. (red.), 1998, Karczew. Dzieje miasta i okolic, Rada Miejska, Karczew.

Sidoruk-Gościcka M., 2014, Rewitalizacja zdegradowanych terenów miejskich - nowe oblicze miasta. Rynek przy ul. Orlej w Otwocku, praca magisterska. Promotor dr arch. M.E. Sikorska, Wydz. Architektury, Wyższa Szkoła Ekologii i Zarządzania, Warszawa.

Sobierajska I., Sikorska M.E., 2016, Problemy funkcjonowania placu miejskiego w Karczewie w świetle wspótczesnych potrzeb lokalnej społeczności, MAZOWSZE Studia Regionalne, 19, s. 49-70.

Studium Uwarunkowań i Kierunków Zagospodarowania Przestrzennego Miasta Otwocka, Uchwała Nr LII/540/2014 Rady Miasta Otwocka z dnia 10 czerwca 2014 r.

Zemło M., 2003, Małe Miasta. Przestrzenie, Collegium Suprasliense, Supraśl.

Sobierajska I., 2017, Projekt miejscowego planu zagospodarowania przestrzennego miasta Otwocka pn. "Centrum". 


\section{Transformation of city centers of small and medium cities \\ - historical and a new importance of historical urban space}

\section{ABSTRACT}

The aim of this study is to present contemporary problems of development and functioning of historical centers in small and medium-sized cities in Mazovia. Analyzed cities divided into historical (location and pre-location pedigree) as well as new (XIX and XX century cities). Historic city centers have mostly their established position and retain their identity to a greater or lesser extent. In some of these cities, the centers lost their significance in part because of the disappearance or relocation of commercial functions or because of transit traffic through the former central zone. Sometimes the additional reason is the degradation of the buildings as well as the space of the main public spaces.

In new cities, centers often continue to shape. Cities like Otwock usually have a vision of this development and have the courage to decide on a significant scale of transformation in order to exploit the potential of the center-creating railway station. It happens, however, as in Piastów, that not everyone is ready to make bold decisions in this regard.

The article contains general suggestions of proposed actions that strengthen the importance of the city center in general, especially in old towns. For new cities, there is a hint of possible measures to strengthen the process of shaping the center.

Key words: Góra Kalwaria, Karczew, Mława, Otwock, Piastów, Mazovia, small and medium-sized cities, city square, city center

dr inż. arch. Małgorzata Ewa Sikorska, urbanista - specjalizuje się w dziedzinie urbanistyki i planowania przestrzennego. Dydaktyk w Wyższej Szkole Ekologii i Zarządzania, ul. Olszewska 12, 00-792 Warszawa, e-mail: ammes@wp.pl

Malgorzata Ewa Sikorska, PhD Eng Arch, city planner - specializes in urban design and planning. Educator at the University of Ecology and Management, ul.Olszewska 12,00-792 Warszawa, e-mail:ammes@wp.pl

mgr inż. arch. Izabela Sobierajska, urbanista - specjalizuje się w opracowywaniu dokumentów planistycznych dla gmin. Wykładowca w Wyższej Szkole Ekologii i Zarządzania, ul. Olszewska 12, 00-792 Warszawa, e-mail: archisplan@archisplan.pl

Izabela Sobierajska, MSc Eng Arch, urban planner - specializes in developing planning documents for municipalities. Assistant at the University of Ecology and Management, ul. Olszewska 12, 00-792 Warszawa, e-mail: archisplan@archisplan.pl 